\title{
1 Assessment of strict autumn-winter emission controls on air 2 quality in the Beijing-Tianjin-Hebei region
}

\author{
3 Gongda $\mathrm{Lu}^{1}$, Eloise A. Marais ${ }^{2}$, Tuan V. Vu ${ }^{1, a}$, Jingsha $\mathrm{Xu}^{1, \mathrm{~b}}$, Zongbo Shi ${ }^{1}$, James D. Lee ${ }^{3,4}$, \\ 4 Qiang Zhang ${ }^{5}$, Lu Shen ${ }^{6}$, Gan $\mathrm{Luo}^{7}$, and Fangqun $\mathrm{Yu}^{7}$ \\ $5 \quad{ }^{1}$ School of Geography, Earth and Environmental Sciences, University of Birmingham, Birmingham, B15 2TT, \\ 6 UK \\ $7 \quad{ }^{2}$ Department of Geography, University College London, London, WC1E 6BT, UK \\ $8 \quad{ }^{3}$ Wolfson Atmospheric Chemistry Laboratories, University of York, York, YO10 5DD, UK \\ $9 \quad{ }^{4}$ National Centre for Atmospheric Science, University of York, Heslington, York, YO10 5DD, UK \\ $10{ }^{5}$ Ministry of Education Key Laboratory for Earth System Modeling, Department of Earth System Science, \\ 11 Tsinghua University, Beijing, 100084, China \\ 12 'John A. Paulson School of Engineering and Applied Sciences, Harvard University, Cambridge, MA 02138, USA \\ $13{ }^{7}$ Atmospheric Sciences Research Center, State University of New York at Albany, 251 Fuller Road, Albany, New \\ 14 York, 12203, USA \\ 15 anow at: School of Public Health, Imperial College London, London, W2 1PG, UK \\ 16 bNow at: Department of Chemistry, University of Warwick, Coventry, CV4 7AL, UK \\ 17 Correspondence to: Gongda Lu (gx1642@student.bham.ac.uk) and Eloise A. Marais (e.marais@ucl.ac.uk)
}

Abstract. Strict seasonal emission controls are a popular measure in China for addressing severe air pollution, in particular fine particulate matter $\left(\mathrm{PM}_{2.5}\right)$. Here we evaluate the efficacy of these measures, with a particular focus on the strict emission controls imposed on pollution sources in 28 cities in and around the Beijing-Tianjin-Hebei region (BTH) in autumn-winter 2017/2018. For this we use the GEOS-Chem chemical transport model and air pollutant measurements from the national and Beijing local monitoring networks, after evaluating the network data with independent measurements and correcting large biases in the bottom-up emissions inventory. The network measurements are temporally consistent ( $r>0.9$ for $\mathrm{PM}_{2.5}$ and $r>0.7$ for gases) with the independent measurements, though with systematic differences of 5-17\% for nitrogen dioxide $\left(\mathrm{NO}_{2}\right)$ and $16-28 \%$ for carbon monoxide (CO). The average decrease in monitoring network PM $_{2.5}$ in BTH in autumn-winter 2017/2018 relative to the previous year is $27 \%$, declining from 103 to $75 \mu \mathrm{g} \mathrm{m}^{-3}$. The regional decline in $\mathrm{PM}_{2.5}$ in the model is $20 \%$, exceeding the regional target of $15 \%$. According to the model, pollution control measures led to decline in $\mathrm{PM}_{2.5}$ precursor emissions of $0.27 \mathrm{Tg} \mathrm{NO}_{\mathrm{x}}$ (as $\left.\mathrm{NO}\right), 0.66 \mathrm{Tg}$ sulfur dioxide $\left(\mathrm{SO}_{2}\right), 70 \mathrm{Gg}$ organic carbon $(\mathrm{OC})$, and 50 Gg black carbon (BC). We find though that these alone only lead to an $8 \%$ decline in $\mathrm{PM}_{2.5}$ and that interannual variability in meteorology accounts for more than half $(57 \%)$ the decline. This demonstrates that year-on-year comparisons are misleading for assessing the efficacy of air pollution measures and should be taken into consideration when extending such measures beyond BTH.

\section{Introduction}

Strict seasonal emission controls are an increasingly popular measure to reduce severe air pollution in China, in particular elevated concentrations of fine particles, or $\mathrm{PM}_{2.5}$, in autumn-winter. The Chinese government improved such measures in 28 cities in and around the Beijing-Tianjin-Hebei region (BTH) (so-called " $2+26$ " cities) in 
northern China in autumn and winter 2017/2018. Targets were set to reduce regional mean $\mathrm{PM}_{2.5}$ by $15 \%$ and city-specific $\mathrm{PM}_{2.5}$ by 10-25\% relative to the previous year (MEE, 2017). BTH experiences severe air pollution in China despite substantial decline in $\mathrm{PM}_{2.5}$ of $~ 40 \%$ from 2013 to 2017 from enacting emission controls as part of the 5-year Action Plans (Zhang et al., 2019). Annual mean PM $_{2.5}$ in BTH in 2017 was $64 \mu \mathrm{g} \mathrm{m}^{-3}$ (Wang et al., 2019); far greater than the national standard of $35 \mu^{-3} \mathrm{~m}^{-3}$ (MEE, 2012) and the World Health Organization (WHO) guideline of $10 \mu \mathrm{g} \mathrm{m}^{-3}$. Severe pollution days (defined as days with 24-hour mean $\mathrm{PM}_{2.5} \geq 150 \mu \mathrm{g} \mathrm{m}^{-3}$ ), mostly in autumn and winter, have declined in frequency, but still occurred in 78 days in 2016. Down from 122 days in 2013 (Li et al., 2019a). Severe $\mathrm{PM}_{2.5}$ pollution is due to a combination of large primary emissions of particles and gas-phase precursors from multiple sources (Zhang et al., 2018), very active heterogeneous chemistry enhancing formation of secondary inorganic and organic aerosols (Huang et al., 2014), and accumulation of pollution due to meteorological conditions such as low windspeeds, shallow planetary boundary layer and high relative humidity (RH) (An et al., 2019; Bei et al., 2020; Le et al., 2020; Wu et al., 2019).

Dominant local $\mathrm{PM}_{2.5}$ sources in BTH in autumn-winter include sustained contributions from the energy sector and road traffic (Tong et al., 2020), and seasonal contributions from industrial and residential combustion of coal and other solid fuels (Ma et al., 2017; Yun et al., 2020), and widespread burning of crop residue (Li et al., 2020c). Mitigation measures in China have led to a nation-wide decrease in emissions of the primary $\mathrm{PM}_{2.5}$ components black carbon (BC) and organic carbon (OC) of $28 \%$ for BC and $32 \%$ for OC from 2013 to 2017 (Zheng et al., 2018). Emissions of prominent gas-phase $\mathrm{PM}_{2.5}$ precursors such as nitrogen oxides $\left(\mathrm{NO}_{\mathrm{x}} \equiv \mathrm{NO}+\mathrm{NO}_{2}\right)$ and sulfur dioxide $\left(\mathrm{SO}_{2}\right)$ have declined by $21 \%$ for $\mathrm{NO}_{\mathrm{x}}$ and $59 \%$ for $\mathrm{SO}_{2}$ over the same time period. Trends in other $\mathrm{PM}_{2.5}$ precursors are less certain. Emissions of ammonia $\left(\mathrm{NH}_{3}\right)$, mostly from agriculture, are likely to have increased or remained constant (Zheng et al., 2018). Similar to $\mathrm{NH}_{3}$, emissions of non-methane volatile organic compounds (NMVOCs), mostly from industrial activity and solvent use, are either stable or increasing (Li et al., 2019c; Liu et al., 2018b; Zhang et al., 2017a; Zheng et al., 2018). Non-local sources also make a substantial contribution to $\mathrm{PM}_{2.5}$ in BTH throughout the year. Dong et al. (2020) used a regional air quality model to estimate that regional transport of non-local $\mathrm{PM}_{2.5}$ accounted for 33-68\% of total monthly mean $\mathrm{PM}_{2.5}$ in BTH in 2017.

Many mitigation measures were implemented in autumn-winter $2017 / 2018$ to reduce $\mathrm{PM}_{2.5}$ in the 28 cities in and around BTH. These are detailed in the "Air Pollution Action Plan in Autumn and Winter of 2017-2018 for the Beijing-Tianjin-Hebei Region and its Surrounding Areas" report by the Chinese Ministry of Ecology and Environment (MEE) (MEE, 2017). Briefly, these include a sector-wide cap on total consumption of coal, phaseout of small inefficient and outdated industrial coal-fired boilers, reduction in production capacity of heavy industries such as iron and cement, switching from coal to cleaner fuels in homes, and mandated controls on construction site fugitive dust emissions. Other short-term and reactionary measures included shutdown of intensive industries and construction sites throughout the emission control period and instantaneous shutdown of additional industrial plants in response to forecasts of elevated $\mathrm{PM}_{2.5}$. Tougher emission standards and higher quality vehicular fuel were imposed on on-road vehicles. Agricultural residue burning was banned and strictly enforced, and installation of emission control technologies were mandated for all large emitters of industrial NMVOCs. The MEE used national network observations of $\mathrm{PM}_{2.5}$ to determine that regional reduction targets were achieved in BTH and that only 3 of the 28 cities did not meet their city-specific targets (MEE, 2018). 
As demonstrated by studies assessing changes in air quality during the lockdown period in response to the SARSCoV-2 pandemic, variability in meteorology is also a large contributor to fluctuations in air quality in BTH (Le et al., 2020; Shi et al., 2021). This necessitates that assessment of the efficacy of such measures includes detailed understanding of the contribution of strict emission controls and other factors like meteorology. A recent study by Zhang et al. (2021) assessed city-scale changes in air quality in each of the 28 cities using the high-resolution Community Multi-Scale Air Quality model coupled to the Weather Research and Forecasting Model for meteorology (CMAQ-WRF). CMAQ-WRF was driven with a national bottom-up inventory for the year preceding the emission controls and a regional bottom-up emission inventory for the year of the emission control period. They determined that the contribution of emission controls to the decrease in simulated $\mathrm{PM}_{2.5}$ in each city ranged from $2 \%$ to $82 \%$ and that meteorology was often a dominant contributor, ranging from $18 \%$ to $98 \%$. Here we take a regional perspective, after correcting for large biases in the bottom-up emission inventories for BTH with the China national and Beijing regional monitoring network observations which we also assess against independent measurements. We apply the corrected inventory to the GEOS-Chem chemical transport model (CTM) to determine regional-scale emission reductions resulting from strict mitigation measures in autumn-winter 2017/2018 and the contribution of these and meteorology to improved regional air quality, as such measures are now widely adopted in China.

\section{Air pollutant concentration changes detected with the national and local monitoring networks}

Ambient monitoring of $\mathrm{PM}_{2.5}$ and trace gases in BTH includes reference monitors from the China National Environmental Monitoring Network (CNEMN) and the local Beijing Municipal Environmental Monitoring Network (BJMEMN) (Zhang et al., 2020). We use observations of hourly $\mathrm{SO}_{2}, \mathrm{NO}_{2}, \mathrm{CO}$, and $\mathrm{PM}_{2.5}$ for the autumn-winter emission reduction period (2017/2018) and the preceding year (2016/2017) at sites operational in both years: 402 for CNEMN and 35 for BJMEMN. Data from both networks are from the Sina Air Quality Data Platform (http://beijingair.sinaapp.com/; last accessed 17 October 2020, now hosted at https://quotsoft.net/air/). Data from both networks have been extensively used to quantify changes in surface air pollution (Li et al., 2019b; Silver et al., 2018; Wan et al., 2021; Wang et al., 2014; Zhai et al., 2019), though independent evaluation of the measurements is limited. A previous study used statistical techniques and intercomparison of air pollutant measurements to determine that outliers make only a small contribution $(\leq 1 \%)$ to measurements of air pollutants relevant to this work (Wu et al., 2018).

We assess CNEMN and BJMEMN measurements against $\mathrm{PM}_{2.5}$ from the US Embassy in Beijing and $\mathrm{PM}_{2.5}$ and trace gas $\left(\mathrm{SO}_{2}, \mathrm{NO}_{2}\right.$, and $\left.\mathrm{CO}\right)$ measurements from the winter portion of the intensive Atmospheric Pollution \& Human Health in a Chinese Megacity (APHH) campaign, hereafter referred to as APHH. The APHH campaign included a comprehensive suite of aerosol and gas-phase measurements from the 325-m tower at the urban Institute of Atmospheric Physics (IAP) measurement site and a few air quality measurements at a rural site (Pinggu) located $\sim 60 \mathrm{~km}$ from the Beijing city centre (Shi et al., 2019). APHH data are from the National Environmental Research Council (NERC) Centre for Environmental Data Archive (CEDA) (Fleming et al., 2017). US Embassy $\mathrm{PM}_{2.5}$ measurements in Beijing, obtained with US EPA measurement and quality control protocols (Martini et al., 2015), are from the US Department of State Air Quality Monitoring Program (http://www.stateair.net/; last 
accessed 17 October 2020) for autumn-winter 2016/2017 and from the OpenAQ data portal (http://www.openaq.org/; last accessed 17 October 2020) for autumn-winter 2017/2018. We use APHH data for November-December 2016 and US Embassy PM 2.5 for October 2016-March 2017 and October 2017-March 2018. These are compared to the nearest national and local monitoring network sites. For APHH, these are the CNEMN Aotizhongxin site $\left(39.98^{\circ} \mathrm{N}, 116.40^{\circ} \mathrm{E}\right)$ and the BJMEMN Xizhimenbei site $\left(39.95^{\circ} \mathrm{N}, 116.35^{\circ} \mathrm{E}\right)$, each located $\sim 3 \mathrm{~km}$ from the APHH urban site $\left(39.97^{\circ} \mathrm{N} 116.37^{\circ} \mathrm{E}\right)$. For the US Embassy, these are the CNEMN site Nongzhanguan $\left(39.94^{\circ} \mathrm{N}, 116.46^{\circ} \mathrm{E}\right)$ and the BJMEMN site Dongsihuan $\left(39.94^{\circ} \mathrm{N}, 116.48^{\circ} \mathrm{E}\right)$, each $\sim 1 \mathrm{~km}$ from the US Embassy $\left(39.95^{\circ} \mathrm{N}, 116.47^{\circ} \mathrm{E}\right)$.

Figure 1 compares hourly CNEMN and BJMEMN $\mathrm{PM}_{2.5}$ to APHH and US Embassy $\mathrm{PM}_{2.5}$. $\mathrm{PM}_{2.5}$ from both CNEMN and BJMEMN are temporally consistent with APHH and US Embassy $\mathrm{PM}_{2.5}(r \geq 0.96)$. The surface monitoring networks also reproduce the variance in hourly $\mathrm{PM}_{2.5}$ (Slopes of 1.0-1.1). Network sites are systematically higher than APHH by $10 \%$ for CNEMN and $17 \%$ for BJMEMN, though compared to US Embassy site $\mathrm{PM}_{2.5}$ the difference is small, ranging from negligible (0.2\% less) to 6.4\% more than US Embassy $\mathrm{PM}_{2.5}$. In general, the BJMEMN measurements are 6-17\% more than APHH, likely due to spatial variability in local emissions. The decline in $\mathrm{PM}_{2.5}$ in the control period relative to the previous year at these sites is $43 \%$ according to US Embassy $\mathrm{PM}_{2.5}$, decreasing from $97 \mu \mathrm{g} \mathrm{m}^{-3}$ to $55 \mu \mathrm{g} \mathrm{m}^{-3}$. A similar decline is obtained with the nearby BJMEMN (43\% decline) and CNEMN (42\% decline) sites shown in Fig. 1.

Figure 2 compares hourly trace gas measurements from CNEMN, BJMEMN and APHH. The CNEMN and BJMEMN trace gas instruments include chemiluminescence for $\mathrm{NO}_{2}$, UV fluorescence for $\mathrm{SO}_{2}$, and IR absorption for $\mathrm{CO}$. Though $\mathrm{CO}$ is not a precursor of $\mathrm{PM}_{2.5}$, its abundance affects the oxidative potential of the atmosphere and also offers a means to indirectly assess $\mathrm{PM}_{2.5}$ precursor emissions of NMVOCs that oxidize to form CO. Most measurements from the local and national networks, with the exception of $31 \%$ of the $\mathrm{CNEMN}_{2}$ data and $16 \%$ of the BJMEMN SO 2 data, are above the instrument detection limit (indicated in Fig. 2). The surface network is temporally consistent with APHH ( $r>0.7$ for all species). CNEMN $\mathrm{NO}_{2}$ is $<10 \%$ more than $\mathrm{NO}_{2}$ from $\mathrm{APHH}$, likely due to susceptibility of the monitoring network instruments to interference from decomposition of $\mathrm{NO}_{x}$ reservoir compounds to $\mathrm{NO}_{2}$ (Dunlea et al., 2007; Reed et al., 2016). Shah et al. (2020) estimate a positive bias of $\sim 6 \%$ due to this interference. Differences in $\mathrm{CNEMN} \mathrm{SO}_{2}(19 \%$ less than $\mathrm{APHH})$ and $\mathrm{CO}(16 \%$ more than $\mathrm{APHH})$ are large and reflect differences in variance (CNEMN vs $\mathrm{APHH} \mathrm{SO}$ slope of 0.8, CNEMN vs APHH CO slope of 1.4). BJMEMN exceeds APHH by $17-28 \%$ for all trace gases.

To aid interpretation of the differences between the network sites and independent measurements, we also assess consistency between CNEMN and BJEMN for the sites shown in Figs. 1 and 2 . These are $\sim 5 \mathrm{~km}$ apart and the BJEMN site is closer to a heavily trafficked ring road than the CNEMN site. The sites are strongly correlated for $\mathrm{PM}_{2.5}(r=0.97)$ and all trace gases $(r=0.89-0.92)$, but CNEMN is less than BJEMN by $11 \%$ for $\mathrm{NO}_{2}, 33 \%$ for $\mathrm{SO}_{2}, 9 \%$ for $\mathrm{CO}$, and $6 \%$ for $\mathrm{PM}_{2.5}$ due to the lower relative influence of road traffic sources. This is consistent with the relatively large positive differences between BJEMN and the independent measurements in Figs. 1 and 
Both networks also measure ozone, but we do not consider this here, as ozone pollution is most severe in spring and summer in China (Yang et al., 2020). We estimate mean ozone of $15-19 \mu \mathrm{g} \mathrm{m}^{-3}$ at the two monitoring network sites used in Fig. 2. This can be compared to the summer mean ozone air quality metric, mean maximum daily 8$\mathrm{h}$ average ozone, of 120-160 $\mu \mathrm{g} \mathrm{m}^{-3}$ in northern China (Li et al., 2019b).

We show in Fig. 3 the spatial distribution of the network observed changes in air pollutant concentrations in and around BTH in the control period (autumn-winter 2017/2018) relative to the preceding year (autumn-winter 2016/2017). In what follows, we refer to these time periods as AW2017 for autumn-winter 2017/2018 and AW2016 for autumn-winter 2016/2017. Only CNEMN and BJMEMN sites that are operational in both periods are used. These include 164 sites within the control domain (region shaded grey in Fig. 3) and 273 sites in the surrounding area. The decline in air pollutant concentrations in AW2017 relative to AW2016 at sites within the emission control region is $16 \%$ for $\mathrm{NO}_{2}, 44 \%$ for $\mathrm{SO}_{2}, 31 \%$ for $\mathrm{CO}$, and $29 \%$ for $\mathrm{PM}_{2.5}$, surpassing the $15 \% \mathrm{PM}_{2.5}$ reduction target set for BTH. Surface concentrations of ozone (not shown) increase by $19 \%$ in response to decline in $\mathrm{NO}_{\mathrm{x}}$. Even with this increase, ozone is still substantially lower than in spring and summer (Liu et al., 2018a). Smaller reductions of $0.5 \%$ for $\mathrm{NO}_{2}, 31 \%$ for $\mathrm{SO}_{2}, 13 \%$ for $\mathrm{CO}$, and $10 \%$ for $\mathrm{PM}_{2.5}$ occur in the surrounding area. In the southeast portion of the domain shown in Fig. 3, both $\mathrm{NO}_{2}$ and $\mathrm{PM}_{2.5}$ increase by 5-8\%. Fang et al. (2019) reported an increase in emissions from industries in the non-control area that in Fig. 3 appear to offset air quality improvements that would be expected from decline in influence of pollution from BTH.

\section{BTH air pollution and emissions for the year preceding emission controls}

We use the GEOS-Chem model (version 12.0.0; https://doi.org/10.5281/zenodo.1343547) with the evaluated surface network measurements to constrain precursor emissions of $\mathrm{PM}_{2.5}$ in and around BTH. The model is nested over East Asia $\left(11^{\circ} \mathrm{S}-55^{\circ} \mathrm{N}, 60-150^{\circ} \mathrm{E}\right)$ at a horizontal resolution of $0.5^{\circ} \times 0.625^{\circ}$ (latitude $\times$ longitude). The model is driven with assimilated meteorology from the NASA Modern-Era Retrospective analysis for Research and Applications version 2 (MERRA-2) updated hourly for 2D fields and every 3 hours for 3D fields. Dynamic (3hourly) boundary conditions are from a global simulation at $4^{\circ} \times 5^{\circ}$. Monthly anthropogenic emissions for China in AW2016 are from the regional bottom-up Multi-resolution Emission Inventory for China (MEIC) (http://www.meicmodel.org/; last accessed 4 March 2020) available for 2000-2017 at $0.5^{\circ} \times 0.625^{\circ}$. MEIC includes emissions of $\mathrm{SO}_{2}, \mathrm{NO}_{\mathrm{x}}, \mathrm{CO}, \mathrm{NMVOCs}, \mathrm{NH}_{3}$, and primary particles from $\sim 700$ anthropogenic sources (Zheng et al., 2018; Li et al., 2017). In its implementation in GEOS-Chem, MEIC emissions are lumped into five sectors: industry, power plants, transportation, agriculture and residential. Primary particles are emitted as hydrophobic and hydrophilic BC and OC, and speciated NMVOCs are mapped to those in GEOS-Chem using the NMVOCs species mapping tables in Li et al. (2014).

The model includes detailed coupled gas- and aerosol-phase chemistry to represent the formation and loss of $\mathrm{PM}_{2.5}$. Individual aerosol components are modelled as externally mixed. These include sulfate, nitrate, ammonium (Park et al., 2004; Wang et al., 2013), OC (Heald et al., 2006), BC (Li et al., 2016), dust (Fairlie et al., 2007), and sea salt (Jaegle et al., 2011). Formation of secondary sulfate-nitrate-ammonium aerosols are computed with ISORROPIA-II (Fountoukis and Nenes, 2007). Physical loss processes include dry and wet deposition (Amos et al., 2012; Liu et al., 2001; Wang et al., 1998). We implement a revised treatment of wet scavenging described and 
first implemented in GEOS-Chem by Luo et al. (2019). This replaces fixed values of in-cloud condensation water with dynamic values from MERRA-2. This leads to more rapid wet deposition rates and addresses a positive bias in modelled nitrate and ammonium, in particular in winter, when compared to surface observations in China, Europe, and the US (Luo et al., 2020). We sample the model in AW2016 and AW2017 following two months spin-up before each period of interest for chemical initialization.

We find from initial comparison of the model to the surface observations that the model in AW2016 is considerably less than observed $\mathrm{NO}_{2}$ (by $48 \%$ ), $\mathrm{SO}_{2}$ (by $42 \%$ ), and $\mathrm{CO}$ (by $57 \%$ ) over the entire domain shown in Fig. 3. We attribute this to an underestimate in precursor emissions of these in the MEIC. Previous studies reported that MEIC trends in $\mathrm{NO}_{x}, \mathrm{SO}_{2}$, and $\mathrm{CO}$ emissions are consistent with trends in satellite observations of column densities and weather-normalised surface measurements (Vu et al., 2019; Zheng et al., 2018), but studies assessing and identifying similar underestimates to ours are limited to very local assessment of the inventory. Squires et al. (2020) determined that MEIC NO $\mathrm{NO}_{\mathrm{x}}$ and $\mathrm{CO}$ emissions are overestimated at the urban APHH site from comparison to fluxes calculated using the eddy-covariance method, though their comparison was for different years (measurements in 2016, MEIC in 2013). We calculate scale factors to apply to the MEIC based on our initial comparison to the network site measurements. These include spatially uniform scale factors of 1.5 applied to $\mathrm{NO}_{\mathrm{x}}$ emissions and 2.4 applied to $\mathrm{CO}$ emissions across the whole domain shown in Fig. 3. Spatially

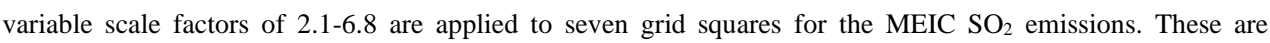
concentrated in Shanxi province west of BTH, a region with large coal-fired power plants (Xie et al., 2018). These grids account for the majority of the domain average $42 \%$ underestimate in modelled $\mathrm{SO}_{2}$ concentrations. Local enhancements in CO can include primary emissions and secondary contributions from oxidation of NMVOCs. Emission inventory estimates of NMVOCs are subject to large uncertainties, mainly due to poorly quantified industrial emissions ( $\mathrm{Li}$ et al., 2017) and lack of reliable data for scattered areal sources such as residential coal burning (Li et al., 2019c; Peng et al., 2019; Shi et al., 2020). We find though that modelled CO is relatively unaffected by NMVOCs emissions. A sensitivity simulation with MEIC NMVOCs emissions increased by $50 \%$ only increases surface $\mathrm{CO}$ concentrations by $0.2 \%$. Given this, we attribute the model underestimate in $\mathrm{CO}$ surface concentrations to the emissions. We do not adjust MEIC primary emissions of BC and OC, due to limited constraints on these from the observations. APHH eddy covariance fluxes of BC obtained in winter suggest a large overestimate (59 times) in MEIC BC emissions (Joshi et al., 2021), though this may be due to very local influence of traffic that is diluted at the resolution of the MEIC (Joshi et al., 2021).

Figure 4 compares GEOS-Chem and monitoring network air pollutant concentrations for BTH and the surrounding area after applying scale factors to MEIC emissions of $\mathrm{SO}_{2}, \mathrm{NO}_{\mathrm{x}}$, and CO. Emissions scaling of $\mathrm{NO}_{\mathrm{x}}$ improves the modelled variance in $\mathrm{NO}_{2}$. The regression slope increases from 0.86 (not shown) to 0.93 (Fig. 4 ). There is still an underestimate in modelled background $\mathrm{NO}_{2}$ (intercept $=-12.8 \mu \mathrm{g} \mathrm{m}^{-3}$ ) that leads to a model $\mathrm{NO}_{2}$ normalized mean bias (NMB) of $-33 \%$. The monitoring network includes sites close to busy roads that may be influenced by local traffic emissions that would be diluted at the 50-67 km resolution of the model. The BJMEMN sites are categorised by location and we find that excluding roadside sites leads to a 5-8\% decrease in mean BJMEMN $\mathrm{NO}_{2}(2-8 \%$ decrease for the other pollutants) and would only partially resolve the remaining underestimate in modelled $\mathrm{NO}_{2}$ in Fig. 4. Other factors that could contribute to the remaining discrepancy include 
short atmospheric lifetime of $\mathrm{NO}_{2}$, relatively coarse model resolution, and a positive 5-17\% bias in the monitoring network measurements (Fig. 2). Any further increases in $\mathrm{MEIC} \mathrm{NO}_{\mathrm{x}}$ emissions would worsen the model NMB in $\mathrm{PM}_{2.5}$ of $15 \%$, as nitrate from oxidation of $\mathrm{NO}_{\mathrm{x}}$ is the dominant component of $\mathrm{PM}_{2.5}(29 \%$ in AW2016 for the entire domain in Fig. 3, according to GEOS-Chem).

Emissions scaling of $\mathrm{SO}_{2}$ improves spatial consistency for concentrations of $\mathrm{SO}_{2}$ from $r=0.54$ (not shown) to $r$ $=0.90$ (Fig. 4). There is still a model bias $-29 \%$ mostly due to 2 grids in Shanxi province with observed $\mathrm{SO}_{2}$ of 161-200 $\mu \mathrm{g} \mathrm{m}^{-3}$ and modelled $\mathrm{SO}_{2}$ of 109-122 $\mathrm{\mu g} \mathrm{m}^{-3}$ (Fig. 4). The model underestimate in CO decreases from $57 \%$ to $-14 \%$ and the remaining model bias may be due to a $16-28 \%$ positive bias in the monitoring network (Fig. 2). The improvement in spatial correlation for $\mathrm{CO}$ is marginal, increasing from $r=0.35$ to $r=0.45$. Scaling MEIC emissions of $\mathrm{SO}_{2}$ and $\mathrm{NO}_{\mathrm{x}}$ increases the modelled $\mathrm{PM}_{2.5} \mathrm{NMB}$ from $8 \%$ with the original emissions to $15 \%$ with the scaled emissions. This may be due to remaining uncertainties in MEIC emissions of BC, $\mathrm{OC}, \mathrm{and} \mathrm{NH}_{3}$.

Figure 5 compares observed and modelled $\mathrm{PM}_{2.5}$ composition at the urban and rural APHH sites. The model overestimates total $\mathrm{PM}_{2.5}$ by $10 \%$ at the urban site and $34 \%$ at the rural site. Components are measured with a semicontinuous analyzer for OC and BC (Han et al., 2014; Kondo et al., 2006) and ion chromatography following particle collection with a Partisol for sulfate, nitrate, and ammonium (Taiwo et al., 2014; Xu et al., 2021). OC is compared instead of organic aerosol (OA), due to uncertainties in conversion of OC to OA (Xing et al., 2013). According to the observations, $\mathrm{OC}$ is the dominant $\mathrm{PM}_{2.5}$ component, with a carbon mass contribution to total $\mathrm{PM}_{2.5}$ of $23 \%$ at the urban site and $33 \%$ at the rural site. The total contribution of secondary inorganic aerosols is similar (31\%) at both sites and includes $9 \%$ sulfate, $13 \%$ nitrate, and $9 \%$ ammonium at the urban site and similar contributions ( $8 \%$ sulfate, $13 \%$ nitrate, and $10 \%$ ammonium) at the rural site. $\mathrm{BC}$ is $4 \%$ of total $\mathrm{PM}_{2.5}$ at both sites The model underestimates OC (9\% urban, $10 \%$ rural) and sulfate (both $4 \%$ ), overestimates nitrate $(28 \%, 30 \%)$, slightly overpredicts BC (4\%, 5\%), and is similar for ammonium (both $10 \%)$.

Previous studies have reported similar biases in simulated OC, sulfate and nitrate in China from GEOS-Chem (Miao et al., 2020) and other CTMs (Chen et al., 2019; Gao et al., 2018). Miao et al. (2020) reported a year-round underestimate in OA that they attribute to biases in precursor emissions and lack of seasonality in fixed secondary OA (SOA) yields used to estimate SOA formation from precursor emissions of NMVOCs. They also identified a year-round underestimate in sulfate that peaks at 54\% in winter (Miao et al., 2020), similar to the 50\% underestimate we obtain at the urban IAP site. The model underestimate in sulfate may in part be due to the remaining underestimate in $\mathrm{MEIC} \mathrm{SO}_{2}$ emissions (Fig. 4) after scaling $\mathrm{MEIC} \mathrm{SO}_{2}$ emissions. The model may also be missing key sulfate formation processes during haze events (Bloss et al., 2021; Wang et al., 2016; Wang et al., 2020), though the measurements may also be impacted by interference from hydroxymethane sulfonate (HMS) (Moch et al., 2018; Song et al., 2019). The overestimate in modelled nitrates is a common issue and has been attributed by Miao et al. (2020) to an overestimate in aerosol nitrate precursors at night exacerbated by errors in boundary layer dynamics. Despite biases in $\mathrm{PM}_{2.5}$ composition, the model reproduces day-to-day variability in 24-hour mean $\mathrm{PM}_{2.5}(r=0.66-0.71)$ and its components $(r=0.50-0.78)$ at both sites. 
Figure 6 shows total anthropogenic emissions of gaseous $\mathrm{PM}_{2.5}$ precursors and primary $\mathrm{PM}_{2.5}(\mathrm{OC}$ and $\mathrm{BC})$ for AW2016 obtained after applying scaling factors to the MEIC based on discrepancies in modelled and observed air pollutant concentrations. Total anthropogenic emissions in BTH (area shaded grey in Fig. 3) in AW2016, the year prior to the control period, are $2.4 \mathrm{Tg} \mathrm{NO}_{\mathrm{x}}$ as $\mathrm{NO}, 1.6 \mathrm{Tg} \mathrm{SO}$, $150 \mathrm{Gg} \mathrm{BC}, 240 \mathrm{Gg} \mathrm{OC}$, and $41 \mathrm{Tg} \mathrm{CO}$. NMVOCs $(2.0 \mathrm{Tg} \mathrm{C})$ and $\mathrm{NH}_{3}(0.64 \mathrm{Tg})$ are not shown in Fig. 6, as these are unchanged from AW2016 to AW2017. Though emissions of $\mathrm{NO}_{x}, \mathrm{CO}$ and $\mathrm{SO}_{2}$ increase in AW2016 relative to the default MEIC emissions due to our emissions scaling, there is no change in the relative contribution of different sectors. The major sector contributions include industry for $\mathrm{NO}_{\mathrm{x}}(44 \%), \mathrm{SO}_{2}(56 \%)$, and $\mathrm{CO}(39 \%)$, transport for $\mathrm{NO}_{\mathrm{x}}(34 \%)$, and residential fuel use for domestic heating and cooking for $\mathrm{SO}_{2}(28 \%), \mathrm{CO}(42 \%), \mathrm{BC}(47 \%)$ and $\mathrm{OC}(79 \%)$.

\section{Influence of emissions and meteorology on air quality in AW2017}

To estimate the emission changes in the model due to controls implemented in BTH in AW2017, we regrid the relative changes in the surface air quality observations (Fig. 3) to a $1^{\circ} \times 1.25^{\circ}$ resolution grid to achieve reasonably extensive coverage across the whole domain shown in Fig. 3. For grids without surface observations (17\% of the grids in the emission control region, $51 \%$ outside it), we interpolate across nearest neighbouring grids. Anthropogenic emissions beyond the geographic limits in Fig. 3 are unchanged. Due to lack of observations of $\mathrm{OC}$ and $\mathrm{BC}$ concentrations, we initially use the relative change in total measured $\mathrm{PM}_{2.5}$. This ranges from a decrease in AW2017 relative to AW2016 of 5\% to 53\% in BTH. We find with this initial approach that the model underestimates the percent reduction in $\mathrm{PM}_{2.5}$ in AW2017 relative to AW2016. This suggests that the decline in primary $\mathrm{PM}_{2.5}$ may be greater than the decline in total $\mathrm{PM}_{2.5}$, corroborated by the greater decline in primary $\mathrm{PM}_{2.5}$ emissions in the bottom-up inventories used by Zhang et al. (2021) than the decline in measured total $\mathrm{PM}_{2.5}$ for around half of the 28 cities. This may be because the regulations mostly targeted sources that have large primary $\mathrm{PM}_{2.5}$ emissions, such as coal combustion, industry, vehicles, fugitive dust and biomass burning (Zhang et al., 2017b; Zheng et al., 2017). We iterate to obtain BC and OC emissions scaling factors that are 1.4 times more than the percent change in total $\mathrm{PM}_{2.5}$.

Figure 7 shows the spatial distribution of modelled and observed $\mathrm{PM}_{2.5}$ concentrations and relative changes in $\mathrm{PM}_{2.5}$ in and around BTH. The average decrease in observed $\mathrm{PM}_{2.5}$ is $28 \%$ in BTH, declining from $103 \mu \mathrm{g} \mathrm{m}^{-3}$ in AW2016 to $75 \mu \mathrm{g} \mathrm{m}^{-3}$ in AW 2017. A similar decline is obtained with the model for grids coincident with the sites (25\% decrease from $112 \mu \mathrm{g} \mathrm{m}^{-3}$ in AW2016 to $85 \mu \mathrm{g} \mathrm{m}^{-3}$ in AW2017). The decline in modelled $\mathrm{PM}_{2.5}$ for all BTH grids is $20 \%$ and compared to $16 \%$ for the whole domain. In Beijing, observed $\mathrm{PM}_{2.5}$ decreases from $96 \mu \mathrm{g}$ $\mathrm{m}^{-3}$ in AW2016 to $57 \mathrm{\mu g} \mathrm{m}^{-3}$ in AW2017, a 40\% reduction. The decline in the model for all 13 grids covering Beijing $\left(39.25-41.25^{\circ} \mathrm{N}, 115.3125-117.8125^{\circ} \mathrm{E}\right.$ ) is more modest ( $33 \%$ decline from $75 \mu \mathrm{g} \mathrm{m}^{-3}$ in AW2016 to 50 $\mu \mathrm{g} \mathrm{m}^{-3}$ in AW2017) than the grids coincident with the monitoring network sites. Regardless, both values exceed the 25\% target set for Beijing (MEE, 2017).

Figure 8 further compares observed and modelled relative changes in $\mathrm{PM}_{2.5}$. This confirms the skill of the model at reproducing the relative change in $\mathrm{PM}_{2.5}$, despite an overall positive bias in total $\mathrm{PM}_{2.5}$ (Figs. 4 and 7) and individual $\mathrm{PM}_{2.5}$ components (Fig. 5). The modelled relative changes in $\mathrm{PM}_{2.5}$ are somewhat more spatially consistent with the observations in BTH $(r=0.82)$ than the surrounding area $(r=0.76)$. The variance is closer to 
unity for BTH (slope $=0.84$ ) than the surrounding area (slope $=0.74$ ). The relative change in $\mathrm{PM}_{2.5}$ outside the emission control domain is $-10 \%$ according to the observations, and $-11 \%$ in the coincident model grids. During the emission control period, the area surrounding BTH in the domain shown in Fig. 7 is likely influenced by anthropogenic emissions from neighbouring regions that are the same in AW2017 and AW2016. This may account for the differences in the direction of change for 14 model grids (decline) compared to the observations (increase) in Fig. 8.

The emissions that we estimate for the control period (AW2017) are also shown in Fig. 6. According to our approach, total emissions reductions in AW2017 compared to AW2016 in BTH are 0.27 Tg NO as NO, 0.66 Tg $\mathrm{SO}_{2}, 9.7 \mathrm{Tg} \mathrm{CO}, 70 \mathrm{Gg} \mathrm{OC}$, and $50 \mathrm{Gg}$ BC. Emissions of $\mathrm{NH}_{3}$ and NMVOCs are unchanged due to limited constraints on these. There is an Ammonia Monitoring Network in China (AMoN-China), but there are only 8 sites in BTH, and the data are not publicly available (Pan et al., 2018). Relating $\mathrm{NH}_{3}$ concentrations to emissions is also complicated by its ability to partition to sulfate aerosols (Fu et al., 2017) that decline by $36 \%$, according to the model, in AW2017 relative to AW2016 due to decline in $\mathrm{SO}_{2}$ emissions. There were also no mandatory measures targeting $\mathrm{NH}_{3}$ sources during AW2017. Agricultural activities such as fertilizer and livestock excreta (Huang et al., 2012), dominant $\mathrm{NH}_{3}$ sources in China, are also at a minimum in autumn and winter (Kong et al., 2019). Zhang et al. (2021) reported that $\mathrm{NH}_{3}$ emissions were relatively unchanged in almost half of the 28 cities and varied in others from a 35\% decrease to a 33\% increase. Controls in BTH in AW2017 should have targeted NMVOCs sources, but these have limited effect on $\mathrm{PM}_{2.5}$ according to GEOS-Chem. The sensitivity simulation we conducted with a $50 \%$ increase in NMVOCs emissions only causes a $1 \%$ increase in surface concentrations of $\mathrm{PM}_{2.5}$. Mechanisms leading to the formation of wintertime SOA are not well understood. Field campaigns in winter in Beijing suggest significant SOA formation from oxidation of NMVOCs (Li et al., 2020a; Li et al., 2020b), whereas Wang et al. (2021) propose that rapid aqueous-phase oxidation of primary OA dominates SOA formation and would resolve the observed decline in SOA in Beijing in winter at the same time that NMVOCs emissions have remained relatively constant.

We also quantify the contribution of meteorology to the decline in $\mathrm{PM}_{2.5}$ in AW2017. To do this, we compare modelled $\mathrm{PM}_{2.5}$ from the AW2017 simulation (Fig. 7) to a simulation with AW2017 emissions and AW2016 meteorology. The decline in $\mathrm{PM}_{2.5}$ in BTH due to differences in AW2016 and AW2017 meteorology only is 12 $\mu \mathrm{g} \mathrm{m}^{-3}$ or $57 \%$ of the decline in $\mathrm{PM}_{2.5}$ from changes in both emissions and meteorology. The contribution of meteorology is similar, $54 \%$, in the surrounding area. Our estimate is slightly less than the city-scale study by Zhang et al. (2019). They attribute $70 \%$ of the decline in $\mathrm{PM}_{2.5}$ in $\mathrm{BTH}$ to variation in meteorology using CMAQ driven with WRF meteorology and the national MEIC and regional Beijing emissions inventories. Zhang et al. (2021) identified large variability in the contribution of emissions and meteorology to decline in $\mathrm{PM}_{2.5} \mathrm{across}$ the 28 cities, of $2-82 \%$ for emissions and $18-98 \%$ for meteorology. We find that the meteorological factors contributing to decline in $\mathrm{PM}_{2.5}$ in $\mathrm{BTH}$ in AW2017 include dilution and dispersion of pollution due to stronger south-easterly winds and a 7\% higher planetary boundary layer in AW2017 than AW2016. Efficiency of formation of secondary inorganic aerosols would also be less in AW2017 than AW2016 in response to 5\% lower RH. Interannual variability in RH has similarly been identified as the cause for sustained air pollution over BTH despite a dramatic decline in precursor emissions from lockdown measures imposed to mitigate the spread of the SARS- 
CoV-2 virus (Le et al., 2020). The meteorological factors that we identified with GEOS-Chem are consistent with

\section{Conclusions} in autumn-winter 2017/2018 to address severe air pollution, specifically fine particles $\left(\mathrm{PM}_{2.5}\right)$. We used national and local surface monitoring network observations of $\mathrm{PM}_{2.5}$ and trace gases with the GEOS-Chem model to assess the efficacy of emission controls, following evaluation of the network with independent measurements.

$\mathrm{PM}_{2.5}$ and trace gases $\left(\mathrm{NO}_{2}, \mathrm{SO}_{2}\right.$ and $\left.\mathrm{CO}\right)$ from the surface networks are temporally consistent with independent measurements ( $r>0.9$ for $\mathrm{PM}_{2.5}$ and $r>0.7$ for gases) and exhibit discrepancies that are in large part due to variability of these in the urban environment. According to these networks, $\mathrm{PM}_{2.5}$ in $\mathrm{BTH}$ decreased by $28 \%$ from $103 \mu \mathrm{g} \mathrm{m}^{-3}$ to $75 \mu \mathrm{g} \mathrm{m}^{-3}$ in the control period relative to the previous year, exceeding the regional target of $15 \%$. The model with emissions scaled to address large biases in $\mathrm{NO}_{\mathrm{x}}, \mathrm{SO}_{2}$, and $\mathrm{CO}$ emissions, reproduces the spatial distribution in $\mathrm{PM}_{2.5}(r=0.68)$. Despite a $15 \%$ positive bias in total $\mathrm{PM}_{2.5}$ and large biases in $\mathrm{PM}_{2.5}$ composition, the model captures the relative decline in $\mathrm{PM}_{2.5}$ in $\mathrm{BTH}$ of $25 \%$. According to the model constrained with the network measurements, decline in emissions in BTH due to strict controls are $0.27 \mathrm{Tg} \mathrm{NO}_{\mathrm{x}}$ as $\mathrm{NO}, 0.66 \mathrm{Tg} \mathrm{SO}_{2}$, 9.7 Tg CO, $70 \mathrm{Gg}$ OC, and $50 \mathrm{Gg}$ BC. These account for less than half the observed decline in $\mathrm{PM}_{2.5}$ and alone lead to an $8 \%$ reduction in $\mathrm{PM}_{2.5}$, falling shorting of $\mathrm{PM}_{2.5}$ reduction target. The remainder is due to meteorology, specifically a deeper planetary boundary layer, stronger winds, and lower relative humidity during the control period.

This supports the need for much stricter emissions controls in BTH and other parts of China where these controls are now adopted.

\section{Data Availability}

The GEOS-Chem model outputs used in this study are available at: https://github.com/GongdaLu/BTH_emission_control.

GLu performed the GEOS-Chem simulations, analysed the model and measurement data, and prepared the manuscript. EAM assisted in the writing and provided supervisory guidance, with co-supervision and editorial contributions from ZS. JDL provided APHH gas concentration data. ZS, TVV and JX performed PM composition analyses and provided guidance on using APHH data. QZ provided the original MEIC emission inventory that LS processed for input to GEOS-Chem. GLuo and FY provided source codes for the updated wet scavenging scheme in GEOS-Chem.

\section{Competing Interests}

The authors declare that they have no conflicts of interest. 
https://doi.org/10.5194/acp-2021-428

Preprint. Discussion started: 2 August 2021

(C) Author(s) 2021. CC BY 4.0 License.

389 Acknowledgements

390 This work was funded by a China Scholarship Council scholarship awarded to GLu and a NERC/EPSRC grant

391 (grant number EP/R513465/1) awarded to EAM. ZS acknowledges funding from the NERC APHH-Beijing

392 programme (grant number NE/N007190/1).

393 


\section{References}

Amos, H. M., Jacob, D. J., Holmes, C. D., Fisher, J. A., Wang, Q., Yantosca, R. M., Corbitt, E. S., Galarneau, E., Rutter, A. P., Gustin, M. S., Steffen, A., Schauer, J. J., Graydon, J. A., St Louis, V. L., Talbot, R. W., Edgerton, E. S., Zhang, Y., and Sunderland, E. M.: Gas-particle partitioning of atmospheric $\mathrm{Hg}$ (II) and its effect on global mercury deposition, Atmos. Chem. Phys., 12, 591-603, https://doi.org/10.5194/acp-12-591-2012, 2012.

An, Z., Huang, R. J., Zhang, R., Tie, X., Li, G., Cao, J., Zhou, W., Shi, Z., Han, Y., Gu, Z., and Ji, Y.: Severe haze in northern China: A synergy of anthropogenic emissions and atmospheric processes, Proc. Natl. Acad. Sci. USA, 116, 8657-8666, https://doi.org/10.1073/pnas.1900125116, 2019.

Bei, N., Li, X., Tie, X., Zhao, L., Wu, J., Li, X., Liu, L., Shen, Z., and Li, G.: Impact of synoptic patterns and meteorological elements on the wintertime haze in the Beijing-Tianjin-Hebei region, China from 2013 to 2017, Sci. Total. Environ., 704, 135210, https://doi.org/10.1016/j.scitotenv.2019.135210, 2020.

Bloss, W. J., Kramer, L., Crilley, L. R., Vu, T., Harrison, R. M., Shi, Z., Lee, J. D., Squires, F. A., Whalley, L. K., Slater, E., Woodward-Massey, R., Ye, C., Heard, D. E., Tong, S., Hou, S., Sun, Y., Xu, J., Wei, L., and Fu, P.: Insights into air pollution chemistry and sulphate formation from nitrous acid (HONO) measurements during haze events in Beijing, Faraday Discuss., 226, 223-238, 10.1039/d0fd00100g, 2021.

Chen, L., Gao, Y., Zhang, M. G., Fu, J. S., Zhu, J., Liao, H., Li, J. L., Huang, K., Ge, B. Z., Wang, X. M., Lam, Y. F., Lin, C. Y., Itahashi, S., Nagashima, T., Kajino, M., Yamaji, K., Wang, Z. F., and Kurokawa, J.: MICS-Asia III: multi-model comparison and evaluation of aerosol over East Asia, Atmos. Chem. Phys., 19, 11911-11937, https://doi.org/10.5194/acp-19-11911-2019, 2019.

Dong, Z., Wang, S., Xing, J., Chang, X., Ding, D., and Zheng, H.: Regional transport in Beijing-Tianjin-Hebei region and its changes during 2014-2017: The impacts of meteorology and emission reduction, Sci. Total. Environ., 737, 139792, https://doi.org/10.1016/j.scitotenv.2020.139792, 2020.

Dunlea, E. J., Herndon, S. C., Nelson, D. D., Volkamer, R. M., San Martini, F., Sheehy, P. M., Zahniser, M. S., Shorter, J. H., Wormhoudt, J. C., Lamb, B. K., Allwine, E. J., Gaffney, J. S., Marley, N. A., Grutter, M., Marquez, C., Blanco, S., Cardenas, B., Retama, A., Villegas, C. R. R., Kolb, C. E., Molina, L. T., and Molina, M. J.: Evaluation of nitrogen dioxide chemiluminescence monitors in a polluted urban environment, Atmos. Chem. Phys., 7, 2691-2704, https://doi.org/10.5194/acp-7-2691-2007, 2007.

Fairlie, T. D., Jacob, D. J., and Park, R. J.: The impact of transpacific transport of mineral dust in the United States, Atmos. Environ., 41, 1251-1266, https://doi.org/10.1016/j.atmosenv.2006.09.048, 2007.

Fang, D., Chen, B., Hubacek, K., Ni, R., Chen, L., Feng, K., and Lin, J.: Clean air for some: Unintended spillover effects of regional air pollution policies, Sci. Adv., 5, eaav4707, https://doi.org/10.1126/sciadv.aav4707, 2019.

Fleming, Z. L., Lee, J. D., Liu, D., Acton, J., Huang, Z., Wang, X., Hewitt, N., Crilley, L., Kramer, L., Slater, E., Whalley, L., Ye, C., and Ingham, T.: APHH: Atmospheric measurements and model results for the Atmospheric Pollution \& Human Health in a Chinese Megacity, available at: http://catalogue.ceda.ac.uk/uuid/648246d2bdc7460b8159a8f9daee7844 (last access: 04 March 2021), 2017.

Fountoukis, C. and Nenes, A.: ISORROPIA II: a computationally efficient thermodynamic equilibrium model for $\mathrm{K}^{+}-\mathrm{Ca}^{2+}-\mathrm{Mg}^{2+}-\mathrm{NH}_{4}^{+}-\mathrm{Na}^{+}-\mathrm{SO}_{4}{ }^{2-}-\mathrm{NO}_{3}^{-}-\mathrm{Cl}^{-}-\mathrm{H}_{2} \mathrm{O}$ aerosols, Atmos. Chem. Phys., 7, 4639-4659, https://doi.org/10.5194/acp-7-4639-2007, 2007.

Fu, X., Wang, S. X., Xing, J., Zhang, X. Y., Wang, T., and Hao, J. M.: Increasing Ammonia Concentrations Reduce the Effectiveness of Particle Pollution Control Achieved via $\mathrm{SO}_{2}$ and $\mathrm{NO}_{\mathrm{X}}$ Emissions Reduction in East China, Environ. Sci. Tech. Lett., 4, 221-227, https://doi.org/10.1021/acs.estlett.7b00143, 2017. 
Gao, M., Han, Z. W., Liu, Z. R., Li, M., Xin, J. Y., Tao, Z. N., Li, J. W., Kang, J. E., Huang, K., Dong, X. Y., Zhuang, B. L., Li, S., Ge, B. Z., Wu, Q. Z., Cheng, Y. F., Wang, Y. S., Lee, H. J., Kim, C. H., Fu, J. S. S., Wang, T. J., Chin, M. A., Woo, J. H., Zhang, Q., Wang, Z. F., and Carmichael, G. R.: Air quality and climate change, Topic 3 of the Model Inter-Comparison Study for Asia Phase III (MICS-Asia III) - Part 1: Overview and model evaluation, Atmos. Chem. Phys., 18, 4859-4884, https://doi.org/10.5194/acp-18-4859-2018, 2018.

Han, T. T., Liu, X. G., Zhang, Y. H., Qu, Y., Gu, J. W., Ma, Q., Lu, K. D., Tian, H. Z., Chen, J., Zeng, L. M., Hu, M., and Zhu, T.: Characteristics of Aerosol Optical Properties and Their Chemical Apportionments during CAREBeijing 2006, Aerosol Air Qual. Res., 14, 1431-1442, https://doi.org/10.4209/aaqr.2013.06.0203, 2014.

Heald, C. L., Jacob, D. J., Turquety, S., Hudman, R. C., Weber, R. J., Sullivan, A. P., Peltier, R. E., Atlas, E. L., de Gouw, J. A., Warneke, C., Holloway, J. S., Neuman, J. A., Flocke, F. M., and Seinfeld, J. H.: Concentrations and sources of organic carbon aerosols in the free troposphere over North America, J. Geophys. Res. Atmos., 111, D23S47, https://doi.org/10.1029/2006jd007705, 2006.

Huang, R. J., Zhang, Y., Bozzetti, C., Ho, K. F., Cao, J. J., Han, Y., Daellenbach, K. R., Slowik, J. G., Platt, S. M., Canonaco, F., Zotter, P., Wolf, R., Pieber, S. M., Bruns, E. A., Crippa, M., Ciarelli, G., Piazzalunga, A., Schwikowski, M., Abbaszade, G., Schnelle-Kreis, J., Zimmermann, R., An, Z., Szidat, S., Baltensperger, U., El Haddad, I., and Prevot, A. S.: High secondary aerosol contribution to particulate pollution during haze events in China, Nature, 514, 218-222, https://doi.org/10.1038/nature13774, 2014.

Huang, X., Song, Y., Li, M. M., Li, J. F., Huo, Q., Cai, X. H., Zhu, T., Hu, M., and Zhang, H. S.: A high-resolution ammonia emission inventory in China, Global Biogeochem. Cy., 26, GB1030, https://doi.org/10.1029/2011gb004161, 2012.

Jaegle, L., Quinn, P. K., Bates, T. S., Alexander, B., and Lin, J. T.: Global distribution of sea salt aerosols: new constraints from in situ and remote sensing observations, Atmos. Chem. Phys., 11, 3137-3157, https://doi.org/10.5194/acp-11-3137-2011, 2011.

Joshi, R., Liu, D. T., Nemitz, E., Langford, B., Mullinger, N., Squires, F., Lee, J., Wu, Y. F., Pan, X. L., Fu, P. Q., Kotthaus, S., Grimmond, S., Zhang, Q., Wu, R. L., Wild, O., Flynn, M., Coe, H., and Allan, J.: Direct measurements of black carbon fluxes in central Beijing using the eddy covariance method, Atmos. Chem. Phys., 21, 147-162, https://doi.org/10.5194/acp-21-147-2021, 2021.

Kondo, Y., Komazaki, Y., Miyazaki, Y., Moteki, N., Takegawa, N., Kodama, D., Deguchi, S., Nogami, M., Fukuda, M., Miyakawa, T., Morino, Y., Koike, M., Sakurai, H., and Ehara, K.: Temporal variations of elemental carbon in Tokyo, J. Geophys. Res. Atmos., 111, D12205, https://doi.org/10.1029/2005jd006257, 2006.

Kong, L., Tang, X., Zhu, J., Wang, Z., Pan, Y., Wu, H., Wu, L., Wu, Q., He, Y., Tian, S., Xie, Y., Liu, Z., Sui, W., Han, L., and Carmichael, G.: Improved Inversion of Monthly Ammonia Emissions in China Based on the Chinese Ammonia Monitoring Network and Ensemble Kalman Filter, Environ. Sci. Technol., 53, 12529-12538, https://doi.org/10.1021/acs.est.9b02701, 2019.

Le, T., Wang, Y., Liu, L., Yang, J., Yung, Y. L., Li, G., and Seinfeld, J. H.: Unexpected air pollution with marked emission reductions during the COVID-19 outbreak in China, Science, 369, 702-706, https://doi.org/10.1126/science.abb7431, 2020.

Li, C., Li, Q., Tong, D., Wang, Q., Wu, M., Sun, B., Su, G., and Tan, L.: Environmental impact and health risk assessment of volatile organic compound emissions during different seasons in Beijing, J. Environ. Sci. (China), 93, 1-12, https://doi.org/10.1016/j.jes.2019.11.006, 2020a.

Li, J., Liao, H., Hu, J., and Li, N.: Severe particulate pollution days in China during 2013-2018 and the associated typical weather patterns in Beijing-Tianjin-Hebei and the Yangtze River Delta regions, Environ. Pollut., 248, 74 81, https://doi.org/10.1016/j.envpol.2019.01.124, 2019a. 
Li, K., Jacob, D. J., Liao, H., Shen, L., Zhang, Q., and Bates, K. H.: Anthropogenic drivers of 2013-2017 trends in summer surface ozone in China, Proc. Natl. Acad. Sci. USA, 116, 422-427, https://doi.org/10.1073/pnas.1812168116, 2019b.

Li, K., Liao, H., Mao, Y. H., and Ridley, D. A.: Source sector and region contributions to concentration and direct radiative forcing of black carbon in China, Atmos. Environ., 124, 351-366, https://doi.org/10.1016/j.atmosenv.2015.06.014, 2016.

Li, M., Liu, H., Geng, G. N., Hong, C. P., Liu, F., Song, Y., Tong, D., Zheng, B., Cui, H. Y., Man, H. Y., Zhang, Q., and He, K. B.: Anthropogenic emission inventories in China: a review, Natl. Sci. Rev., 4, 834-866, https://doi.org/10.1093/nsr/nwx150, 2017.

Li, M., Zhang, Q., Streets, D. G., He, K. B., Cheng, Y. F., Emmons, L. K., Huo, H., Kang, S. C., Lu, Z., Shao, M., $\mathrm{Su}, \mathrm{H} ., \mathrm{Yu}, \mathrm{X}$., and Zhang, Y.: Mapping Asian anthropogenic emissions of non-methane volatile organic compounds to multiple chemical mechanisms, Atmos. Chem. Phys., 14, 5617-5638, https://doi.org/10.5194/acp14-5617-2014, 2014.

Li, M., Zhang, Q., Zheng, B., Tong, D., Lei, Y., Liu, F., Hong, C. P., Kang, S. C., Yan, L., Zhang, Y. X., Bo, Y., $\mathrm{Su}, \mathrm{H}$., Cheng, Y. F., and He, K. B.: Persistent growth of anthropogenic non-methane volatile organic compound (NMVOC) emissions in China during 1990-2017: drivers, speciation and ozone formation potential, Atmos. Chem. Phys., 19, 8897-8913, https://doi.org/10.5194/acp-19-8897-2019, 2019c.

Li, Q., Su, G., Li, C., Liu, P., Zhao, X., Zhang, C., Sun, X., Mu, Y., Wu, M., Wang, Q., and Sun, B.: An investigation into the role of VOCs in SOA and ozone production in Beijing, China, Sci. Total. Environ., 720, 137536, https://doi.org/10.1016/j.scitotenv.2020.137536, 2020b.

Li, X. R., Zhang, C. L., Liu, P. F., Liu, J. F., Zhang, Y. Y., Liu, C. T., and Mu, Y. J.: Significant influence of the intensive agricultural activities on atmospheric $\mathrm{PM}_{2.5}$ during autumn harvest seasons in a rural area of the North China Plain, Atmos. Environ., 241, 117844, https://doi.org/10.1016/j.atmosenv.2020.117844, 2020c.

Liu, H., Jacob, D. J., Bey, I., and Yantosca, R. M.: Constraints from ${ }^{210} \mathrm{~Pb}$ and ${ }^{7} \mathrm{Be}$ on wet deposition and transport in a global three-dimensional chemical tracer model driven by assimilated meteorological fields, J. Geophys. Res. Atmos., 106, 12109-12128, https://doi.org/10.1029/2000jd900839, 2001.

Liu, H., Liu, S., Xue, B. R., Lv, Z. F., Meng, Z. H., Yang, X. F., Xue, T., Yu, Q., and He, K. B.: Ground-level ozone pollution and its health impacts in China, Atmos. Environ., 173, 223-230, https://doi.org/10.1016/j.atmosenv.2017.11.014, 2018a.

Liu, M. X., Huang, X., Song, Y., Xu, T. T., Wang, S. X., Wu, Z. J., Hu, M., Zhang, L., Zhang, Q., Pan, Y. P., Liu, $\mathrm{X}$. J., and $\mathrm{Zhu}, \mathrm{T}$.: Rapid $\mathrm{SO}_{2}$ emission reductions significantly increase tropospheric ammonia concentrations over the North China Plain, Atmos. Chem. Phys., 18, 17933-17943, https://doi.org/10.5194/acp-18-17933-2018, $2018 b$.

Luo, G., Yu, F. Q., and Moch, J. M.: Further improvement of wet process treatments in GEOS-Chem v12.6.0: impact on global distributions of aerosols and aerosol precursors, Geosci. Model Dev., 13, 2879-2903, https://doi.org/10.5194/gmd-13-2879-2020, 2020.

Luo, G., Yu, F. Q., and Schwab, J.: Revised treatment of wet scavenging processes dramatically improves GEOSChem 12.0.0 simulations of surface nitric acid, nitrate, and ammonium over the United States, Geosci. Model Dev., 12, 3439-3447, https://doi.org/10.5194/gmd-12-3439-2019, 2019. 
Ma, Q. A., Cai, S. Y., Wang, S. X., Zhao, B., Martin, R. V., Brauer, M., Cohen, A., Jiang, J. K., Zhou, W., Hao, J. M., Frostad, J., Forouzanfar, M. H., and Burnett, R. T.: Impacts of coal burning on ambient $\mathrm{PM}_{2.5}$ pollution in China, Atmos. Chem. Phys., 17, 4477-4491, https://doi.org/10.5194/acp-17-4477-2017, 2017.

Martini, F. M. S., Hasenkopf, C. A., and Roberts, D. C.: Statistical analysis of $\mathrm{PM}_{2.5}$ observations from diplomatic facilities in China, Atmos. Environ., 110, 174-185, https://doi.org/10.1016/j.atmosenv.2015.03.060, 2015.

Ministry of Ecology and Environment, the People's Republic of China (MEE).Ambient air quality standards GB3095-2012 (in Chinese), available at: https://www.mee.gov.cn/ywgz/fgbz/bz/bzwb/dqhjbh/dqhjzlbz/201203/t20120302_224165.shtml (last access: 04 March 2021), 2012.

Ministry of Ecology and Environment, the People's Republic of China (MEE).Air Pollution Comprehensive Management Action Plan in the Autumn and Winter of 2017-2018 for the Beijing-Tianjin-Hebei Region and its Surrounding Areas (in Chinese), available at: https://www.mee.gov.cn/gkml/sthjbgw/sthjbwj/201809/t20180927_630570.htm (last access: 04 March 2021), 2017.

Ministry of Ecology and Environment, the People's Republic of China (MEE).Letter on notifying the completion of air quality targets in the Beijing-Tianjin-Hebei air pollution transmission channel cities in autumn and winter (in Chinese), available at: http://www.mee.gov.cn/gkml/sthjbgw/stbgth/201805/t20180503_435855.htm (last access: 04 March 2021), 2018.

Miao, R. Q., Chen, Q., Zheng, Y., Cheng, X., Sun, Y. L., Palmer, P. I., Shrivastava, M., Guo, J. P., Zhang, Q., Liu, Y. H., Tan, Z. F., Ma, X. F., Chen, S. Y., Zeng, L. M., Lu, K. D., and Zhang, Y. H.: Model bias in simulating major chemical components of $\mathrm{PM}_{2.5}$ in China, Atmos. Chem. Phys., 20, 12265-12284, https://doi.org/10.5194/acp-20-12265-2020, 2020.

Moch, J. M., Dovrou, E., Mickley, L. J., Keutsch, F. N., Cheng, Y., Jacob, D. J., Jiang, J. K., Li, M., Munger, J. W., Qiao, X. H., and Zhang, Q.: Contribution of Hydroxymethane Sulfonate to Ambient Particulate Matter: A Potential Explanation for High Particulate Sulfur During Severe Winter Haze in Beijing, Geophys. Res. Lett., 45, 11969-11979, https://doi.org/10.1029/2018g1079309, 2018.

Pan, Y., Tian, S., Zhao, Y., Zhang, L., Zhu, X., Gao, J., Huang, W., Zhou, Y., Song, Y., Zhang, Q., and Wang, Y.: Identifying Ammonia Hotspots in China Using a National Observation Network, Environ. Sci. Technol., 52, 3926-3934, https://doi.org/10.1021/acs.est.7b05235, 2018.

Park, R. J., Jacob, D. J., Field, B. D., Yantosca, R. M., and Chin, M.: Natural and transboundary pollution influences on sulfate-nitrate-ammonium aerosols in the United States: Implications for policy, J. Geophys. Res. Atmos., 109, D15204, https://doi.org/10.1029/2003jd004473, 2004.

Peng, L. Q., Zhang, Q., Yao, Z. L., Mauzerall, D. L., Kang, S. C., Du, Z. Y., Zheng, Y. X., Xue, T., and He, K. B.: Underreported coal in statistics: A survey-based solid fuel consumption and emission inventory for the rural residential sector in China, Appl. Energ., 235, 1169-1182, https://doi.org/10.1016/j.apenergy.2018.11.043, 2019.

Reed, C., Evans, M. J., Di Carlo, P., Lee, J. D., and Carpenter, L. J.: Interferences in photolytic NO2 measurements: explanation for an apparent missing oxidant?, Atmos. Chem. Phys., 16, 4707-4724, https://doi.org/10.5194/acp16-4707-2016, 2016.

Shah, V., Jacob, D. J., Li, K., Silvern, R. F., Zhai, S. X., Liu, M. Y., Lin, J. T., and Zhang, Q.: Effect of changing $\mathrm{NO}_{\mathrm{x}}$ lifetime on the seasonality and long-term trends of satellite-observed tropospheric $\mathrm{NO}_{2}$ columns over China, Atmos. Chem. Phys., 20, 1483-1495, https://doi.org/10.5194/acp-20-1483-2020, 2020. 
Shi, Y. Q., Xi, Z. Y., Simayi, M., Li, J., and Xie, S. D.: Scattered coal is the largest source of ambient volatile organic compounds during the heating season in Beijing, Atmos. Chem. Phys., 20, 9351-9369, https://doi.org/10.5194/acp-20-9351-2020, 2020.

Shi, Z., Song, C., Liu, B., Lu, G., Xu, J., Van Vu, T., Elliott, R. J. R., Li, W., Bloss, W. J., and Harrison, R. M.: Abrupt but smaller than expected changes in surface air quality attributable to COVID-19 lockdowns, Sci. Adv., 7, eabd6696, https://doi.org/10.1126/sciadv.abd6696, 2021.

Shi, Z. B., Vu, T., Kotthaus, S., Harrison, R. M., Grimmond, S., Yue, S., Zhu, T., Lee, J., Han, Y., Demuzere, M., Dunmore, R. E., Ren, L. J., Liu, D., Wang, Y. L., Wild, O., Allan, J., Acton, W. J., Barlow, J., Barratt, B., Beddows, D., Bloss, W. J., Calzolai, G., Carruthers, D., Carslaw, D. C., Chan, Q., Chatzidiakou, L., Chen, Y., Crilley, L., Coe, H., Dai, T., Doherty, R., Duan, F., Fu, P., Ge, B., Ge, M., Guan, D., Hamilton, J. F., He, K., Heal, M., Heard, D., Hewitt, C. N., Hollaway, M., Hu, M., Ji, D., Jiang, X. J., Jones, R., Kalberer, M., Kelly, F. J., Kramer, L., Langford, B., Lin, C., Lewis, A. C., Li, J., Li, W., Liu, H., Liu, J. F., Loh, M., Lu, K. D., Lucarelli, F., Mann, G., McFiggans, G., Miller, M. R., Mills, G., Monk, P., Nemitz, E., O'Connor, F., Ouyang, B., Palmer, P. I., Percival, C., Popoola, O., Reeves, C., Rickard, A. R., Shao, L. Y., Shi, G. Y., Spracklen, D., Stevenson, D., Sun, Y., Sun, Z. W., Tao, S., Tong, S. R., Wang, Q. Q., Wang, W. H., Wang, X. M., Wang, X. J., Wang, Z. F., Wei, L. F., Whalley, L., Wu, X. F., Wu, Z. J., Xie, P. H., Yang, F. M., Zhang, Q., Zhang, Y. L., Zhang, Y. H., and Zheng, M.: Introduction to the special issue "In-depth study of air pollution sources and processes within Beijing and its surrounding region (APHH-Beijing)", Atmos. Chem. Phys., 19, 7519-7546, https://doi.org/10.5194/acp-19-75192019, 2019.

Silver, B., Reddington, C. L., Arnold, S. R., and Spracklen, D. V.: Substantial changes in air pollution across China during 2015-2017, Environ. Res. Lett., 13, 114012, https://doi.org/10.1088/1748-9326/aae718, 2018.

Song, S. J., Gao, M., Xu, W. Q., Sun, Y. L., Worsnop, D. R., Jayne, J. T., Zhang, Y. Z., Zhu, L., Li, M., Zhou, Z., Cheng, C. L., Lv, Y. B., Wang, Y., Peng, W., Xu, X. B., Lin, N., Wang, Y. X., Wang, S. X., Munger, J. W., Jacob, D. J., and McElroy, M. B.: Possible heterogeneous chemistry of hydroxymethanesulfonate (HMS) in northern China winter haze, Atmos. Chem. Phys., 19, 1357-1371, https://doi.org/10.5194/acp-19-1357-2019, 2019.

Squires, F. A., Nemitz, E., Langford, B., Wild, O., Drysdale, W. S., Acton, W. J. F., Fu, P. Q., Grimmond, C. S. B., Hamilton, J. F., Hewitt, C. N., Hollaway, M., Kotthaus, S., Lee, J., Metzger, S., Pingintha-Durden, N., Shaw, M., Vaughan, A. R., Wang, X. M., Wu, R. L., Zhang, Q., and Zhang, Y. L.: Measurements of traffic-dominated pollutant emissions in a Chinese megacity, Atmos. Chem. Phys., 20, 8737-8761, https://doi.org/10.5194/acp-208737-2020, 2020.

Taiwo, A. M., Beddows, D. C., Calzolai, G., Harrison, R. M., Lucarelli, F., Nava, S., Shi, Z., Valli, G., and Vecchi, R.: Receptor modelling of airborne particulate matter in the vicinity of a major steelworks site, Sci. Total. Environ., 490, 488-500, https://doi.org/10.1016/j.scitotenv.2014.04.118, 2014.

Tong, R. P., Liu, J. F., Wang, W., and Fang, Y. Q.: Health effects of $\mathrm{PM}_{2.5}$ emissions from on-road vehicles during weekdays and weekends in Beijing, China, Atmos. Environ., 223, 117258, https://doi.org/10.1016/j.atmosenv.2019.117258, 2020.

Vu, T. V., Shi, Z. B., Cheng, J., Zhang, Q., He, K. B., Wang, S. X., and Harrison, R. M.: Assessing the impact of clean air action on air quality trends in Beijing using a machine learning technique, Atmos. Chem. Phys., 19, 11303-11314, https://doi.org/10.5194/acp-19-11303-2019, 2019.

Wan, Y. T., Xu, M. Y., Huang, H., and Chen, S. X.: A spatio-temporal model for the analysis and prediction of fine particulate matter concentration in Beijing, Environmetrics, 32, e2648, https://doi.org/10.1002/env.2648, 2021.

Wang, G., Zhang, R., Gomez, M. E., Yang, L., Levy Zamora, M., Hu, M., Lin, Y., Peng, J., Guo, S., Meng, J., Li, J., Cheng, C., Hu, T., Ren, Y., Wang, Y., Gao, J., Cao, J., An, Z., Zhou, W., Li, G., Wang, J., Tian, P., MarreroOrtiz, W., Secrest, J., Du, Z., Zheng, J., Shang, D., Zeng, L., Shao, M., Wang, W., Huang, Y., Wang, Y., Zhu, Y., 
Li, Y., Hu, J., Pan, B., Cai, L., Cheng, Y., Ji, Y., Zhang, F., Rosenfeld, D., Liss, P. S., Duce, R. A., Kolb, C. E., and Molina, M. J.: Persistent sulfate formation from London Fog to Chinese haze, Proc. Natl. Acad. Sci. USA, 113, 13630-13635, https://doi.org/10.1073/pnas.1616540113, 2016.

Wang, J., Li, J., Ye, J., Zhao, J., Wu, Y., Hu, J., Liu, D., Nie, D., Shen, F., Huang, X., Huang, D. D., Ji, D., Sun, X., Xu, W., Guo, J., Song, S., Qin, Y., Liu, P., Turner, J. R., Lee, H. C., Hwang, S., Liao, H., Martin, S. T., Zhang, Q., Chen, M., Sun, Y., Ge, X., and Jacob, D. J.: Fast sulfate formation from oxidation of $\mathrm{SO}_{2}$ by $\mathrm{NO}_{2}$ and $\mathrm{HONO}$ observed in Beijing haze, Nat. Commun., 11, 2844, https://doi.org/10.1038/s41467-020-16683-x, 2020.

Wang, J., Ye, J., Zhang, Q., Zhao, J., Wu, Y., Li, J., Liu, D., Li, W., Zhang, Y., Wu, C., Xie, C., Qin, Y., Lei, Y., Huang, X., Guo, J., Liu, P., Fu, P., Li, Y., Lee, H. C., Choi, H., Zhang, J., Liao, H., Chen, M., Sun, Y., Ge, X., Martin, S. T., and Jacob, D. J.: Aqueous production of secondary organic aerosol from fossil-fuel emissions in winter Beijing haze, Proc. Natl. Acad. Sci. USA, 118, e2022179118, https://doi.org/10.1073/pnas.2022179118, 2021.

Wang, Y., Jacob, D. J., and Logan, J. A.: Global simulation of tropospheric $\mathrm{O}_{3}-\mathrm{NO}_{\mathrm{x}}$-hydrocarbon chemistry: 1. Model formulation, J. Geophys. Res. Atmos., 103, 10713-10725, https://doi.org/10.1029/98jd00158, 1998.

Wang, Y., Ying, Q., Hu, J., and Zhang, H.: Spatial and temporal variations of six criteria air pollutants in 31 provincial capital cities in China during 2013-2014, Environ. Int., 73, 413-422, https://doi.org/10.1016/j.envint.2014.08.016, 2014.

Wang, Y., Zhang, Q. Q., He, K., Zhang, Q., and Chai, L.: Sulfate-nitrate-ammonium aerosols over China: response to 2000-2015 emission changes of sulfur dioxide, nitrogen oxides, and ammonia, Atmos. Chem. Phys., 13, 2635 2652, https://doi.org/10.5194/acp-13-2635-2013, 2013.

Wang, Y. S., Li, W. J., Gao, W. K., Liu, Z. R., Tian, S. L., Shen, R. R., Ji, D. S., Wang, S., Wang, L. L., Tang, G. Q., Song, T., Cheng, M. T., Wang, G. H., Gong, Z. Y., Hao, J. M., and Zhang, Y. H.: Trends in particulate matter and its chemical compositions in China from 2013-2017, Sci. China Earth Sci., 62, 1857-1871, https://doi.org/10.1007/s11430-018-9373-1, 2019.

Wu, H. J., Tang, X., Wang, Z. F., Wu, L., Lu, M. M., Wei, L. F., and Zhu, J.: Probabilistic Automatic Outlier Detection for Surface Air Quality Measurements from the China National Environmental Monitoring Network, Adv. Atmos. Sci., 35, 1522-1532, https://doi.org/10.1007/s00376-018-8067-9, 2018.

Wu, J., Bei, N., Hu, B., Liu, S., Zhou, M., Wang, Q., Li, X., Liu, L., Feng, T., Liu, Z., Wang, Y., Cao, J., Tie, X., Wang, J., Molina, L. T., and Li, G.: Is water vapor a key player of the wintertime haze in North China Plain?, Atmos. Chem. Phys., 19, 8721-8739, https://doi.org/10.5194/acp-19-8721-2019, 2019.

Xie, L. Y., Huang, Y., and Qin, P.: Spatial distribution of coal-fired power plants in China, Environ. Dev. Econ., 23, 495-515, https://doi.org/10.1017/S1355770x18000098, 2018.

Xing, L., Fu, T. M., Cao, J. J., Lee, S. C., Wang, G. H., Ho, K. F., Cheng, M. C., You, C. F., and Wang, T. J.: Seasonal and spatial variability of the $\mathrm{OM} / \mathrm{OC}$ mass ratios and high regional correlation between oxalic acid and zinc in Chinese urban organic aerosols, Atmos. Chem. Phys., 13, 4307-4318, https://doi.org/10.5194/acp-134307-2013, 2013.

Xu, J., Liu, D., Wu, X., Vu, T. V., Zhang, Y., Fu, P., Sun, Y., Xu, W., Zheng, B., Harrison, R. M., and Shi, Z.: Source apportionment of fine organic carbon at an urban site of Beijing using a chemical mass balance model, Atmos. Chem. Phys., 21, 7321-7341, https://doi.org/10.5194/acp-21-7321-2021, 2021.

Yang, G., Liu, Y., and Li, X.: Spatiotemporal distribution of ground-level ozone in China at a city level, Sci. Rep., 10, 7229, https://doi.org/10.1038/s41598-020-64111-3, 2020. 
Yun, X., Shen, G., Shen, H., Meng, W., Chen, Y., Xu, H., Ren, Y., Zhong, Q., Du, W., Ma, J., Cheng, H., Wang, X., Liu, J., Wang, X., Li, B., Hu, J., Wan, Y., and Tao, S.: Residential solid fuel emissions contribute significantly to air pollution and associated health impacts in China, Sci. Adv., 6, eaba7621, https://doi.org/10.1126/sciadv.aba7621, 2020.

Zhai, S. X., Jacob, D. J., Wang, X., Shen, L., Li, K., Zhang, Y. Z., Gui, K., Zhao, T. L., and Liao, H.: Fine particulate matter $\left(\mathrm{PM}_{2.5}\right)$ trends in China, 2013-2018: separating contributions from anthropogenic emissions and meteorology, Atmos. Chem. Phys., 19, 11031-11041, https://doi.org/10.5194/acp-19-11031-2019, 2019.

Zhang, F., Shi, Y., Fang, D., Ma, G., Nie, C., Krafft, T., He, L., and Wang, Y.: Monitoring history and change trends of ambient air quality in China during the past four decades, J. Environ. Manage, 260, 110031, https://doi.org/10.1016/j.jenvman.2019.110031, 2020.

Zhang, Q., Zheng, Y., Tong, D., Shao, M., Wang, S., Zhang, Y., Xu, X., Wang, J., He, H., Liu, W., Ding, Y., Lei, Y., Li, J., Wang, Z., Zhang, X., Wang, Y., Cheng, J., Liu, Y., Shi, Q., Yan, L., Geng, G., Hong, C., Li, M., Liu, F., Zheng, B., Cao, J., Ding, A., Gao, J., Fu, Q., Huo, J., Liu, B., Liu, Z., Yang, F., He, K., and Hao, J.: Drivers of improved $\mathrm{PM}_{2.5}$ air quality in China from 2013 to 2017, Proc. Natl. Acad. Sci. USA, 116, 24463-24469, https://doi.org/10.1073/pnas.1907956116, 2019.

Zhang, X., Wu, Y., Liu, X., Reis, S., Jin, J., Dragosits, U., Van Damme, M., Clarisse, L., Whitburn, S., Coheur, P. F., and Gu, B.: Ammonia Emissions May Be Substantially Underestimated in China, Environ. Sci. Technol., 51, 12089-12096, https://doi.org/10.1021/acs.est.7b02171, 2017a.

Zhang, Y., Cai, J., Wang, S., He, K., and Zheng, M.: Review of receptor-based source apportionment research of fine particulate matter and its challenges in China, Sci. Total. Environ., 586, 917-929, https://doi.org/10.1016/j.scitotenv.2017.02.071, 2017b.

Zhang, Y., Chen, X., Yu, S., Wang, L., Li, Z., Li, M., Liu, W., Li, P., Rosenfeld, D., and Seinfeld, J. H.: Citylevel air quality improvement in the Beijing-Tianjin-Hebei region from 2016/17 to 2017/18 heating seasons: Attributions and process analysis, Environ. Pollut., 274, 116523, https://doi.org/10.1016/j.envpol.2021.116523, 2021.

Zhang, Y. P., Li, X., Nie, T., Qi, J., Chen, J., and Wu, Q.: Source apportionment of $\mathrm{PM}_{2.5}$ pollution in the central six districts of Beijing, China, J. Clean Prod., 174, 661-669, https://doi.org/10.1016/j.jclepro.2017.10.332, 2018.

Zheng, B., Tong, D., Li, M., Liu, F., Hong, C. P., Geng, G. N., Li, H. Y., Li, X., Peng, L. Q., Qi, J., Yan, L., Zhang, Y. X., Zhao, H. Y., Zheng, Y. X., He, K. B., and Zhang, Q.: Trends in China's anthropogenic emissions since 2010 as the consequence of clean air actions, Atmos. Chem. Phys., 18, 14095-14111, https://doi.org/10.5194/acp-18-14095-2018, 2018.

Zheng, M., Yan, C. Q., Wang, S. X., He, K. B., and Zhang, Y. H.: Understanding PM 2.5 sources in China: challenges and perspectives, Natl. Sci. Rev., 4, 801-803, https://doi.org/10.1093/nsr/nwx129, 2017. 

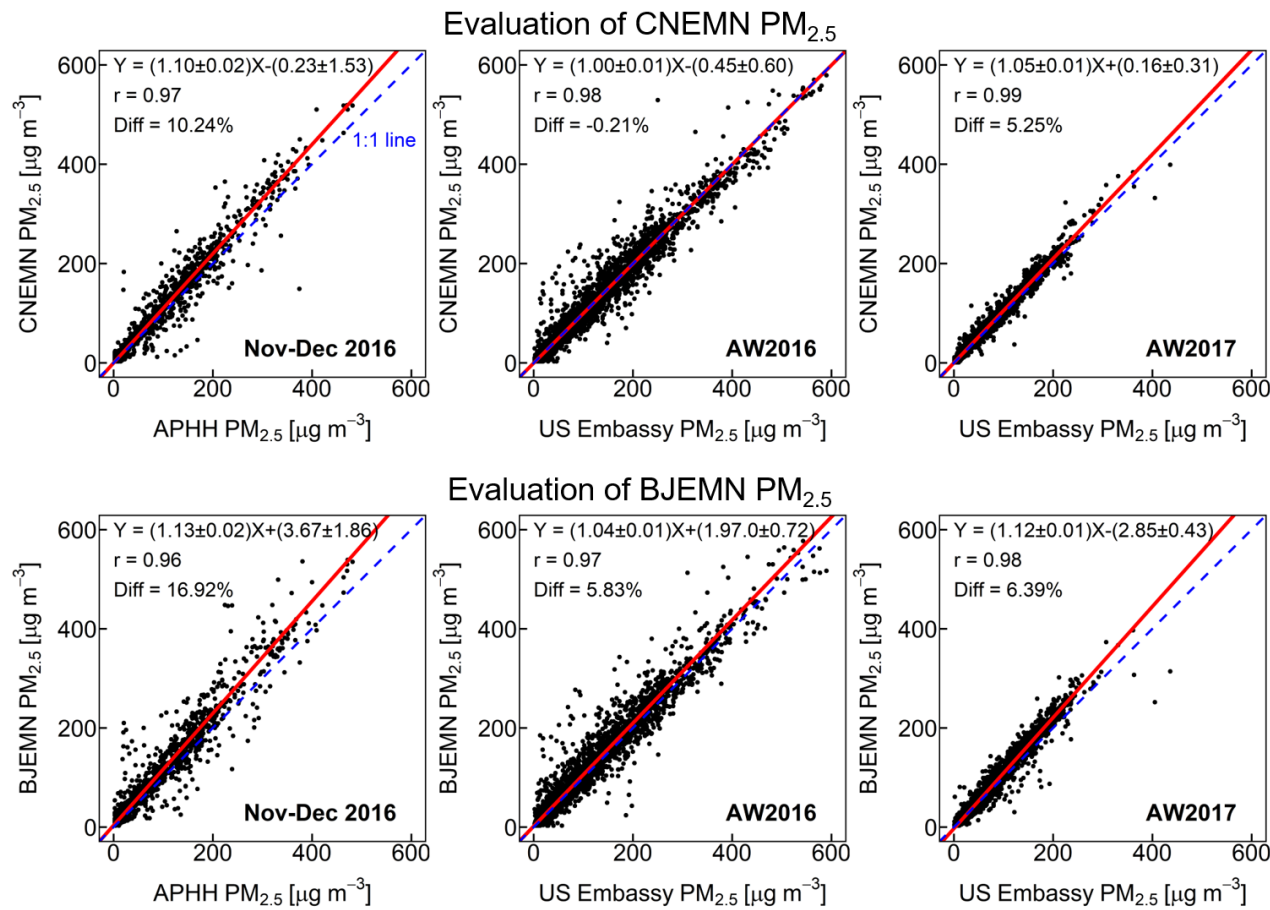

Evaluation of BJEMN $\mathrm{PM}_{2.5}$
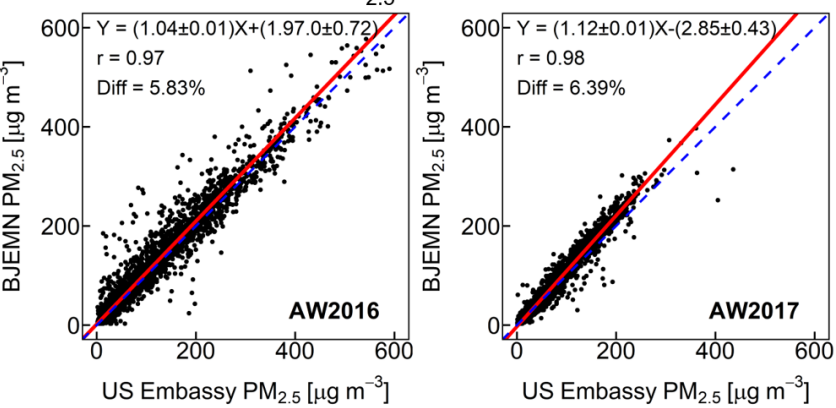

680

Figure 1. Evaluation of local and national network $\mathrm{PM}_{2.5}$ measurements. Points are hourly $\mathrm{PM}_{2.5}$ measurements. The top row compares CNEMN to the APHH urban site (left), and CNEMN to the US Embassy in autumn-winter 2016/2017 (AW2016) (centre) and 2017/2018 (AW2017) (right). The bottom row compares BJMEMN to the APHH urban site (left), and BJMEMN to the US Embassy in AW2016 (centre) and AW2017 (right). Reduced major axis (RMA) regression statistics, Pearson's correlation coefficients (r), and the percent difference (Diff = monitoring network minus independent measurement) are given Lines are the RMA regression (red) and 1:1 line (blue dashed). 
Evaluation of CNEMN trace gases
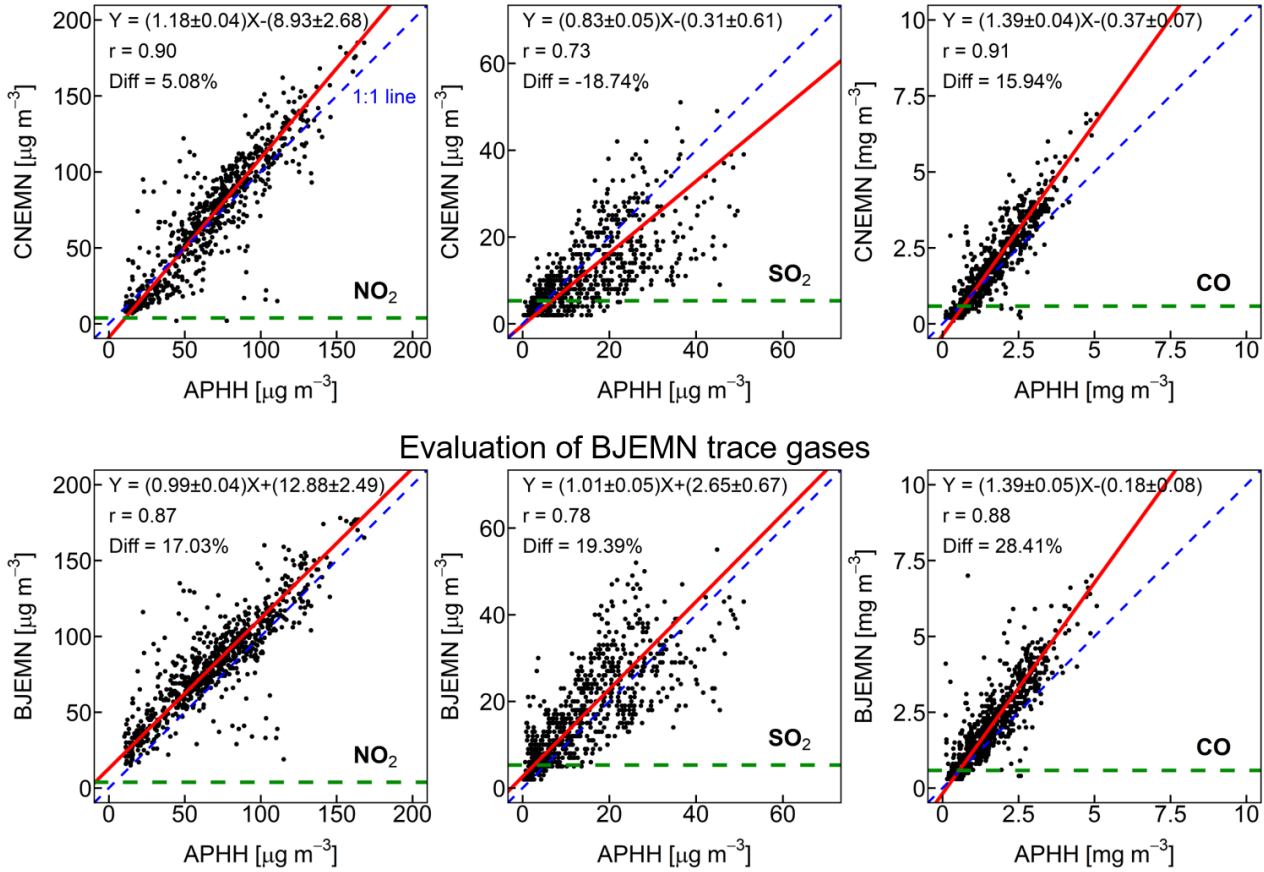

Evaluation of BJEMN trace gases
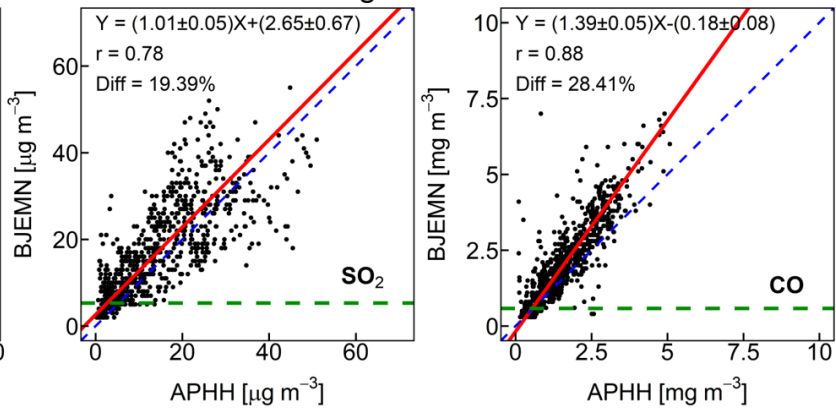

688

689

690

691

692

693

694

Figure 2. Evaluation of local and national network trace gas concentration measurements. Points are hourly measurements. Panels compare CNEMN (top) and BJMEMN (bottom) $\mathrm{NO}_{2}$ (left), $\mathrm{SO}_{2}$ (centre) and CO (right) to the APHH urban site in November-December 2016. RMA regression statistics, Pearson's correlation coefficients $(r)$, and the percent difference (Diff $=$ monitoring network minus independent measurement) are given. Lines are the RMA regression (red) and 1:1 line (blue dashed). The green dashed line is the reported monitoring network instrument detection limit (MEE, 2012). 
https://doi.org/10.5194/acp-2021-428

Preprint. Discussion started: 2 August 2021

(c) Author(s) 2021. CC BY 4.0 License.
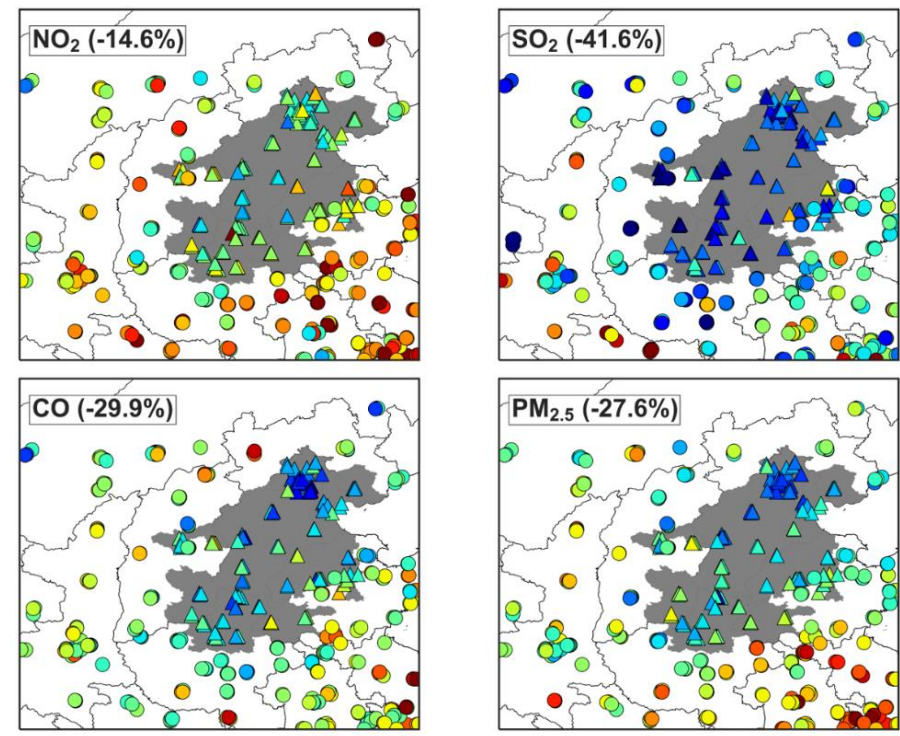

695

696

697

698

699
$-60 \%-50 \%-40 \%-30 \%-20 \%-10 \% \quad 0 \quad+10 \%+20 \%+30 \%$ Relative change in surface air pollution

Figure 3. Change in surface air pollution in BTH and the surrounding area in AW2017 relative to AW2016. Individual points are monitoring network site changes for the target region (triangles within area shaded grey) and the surrounding area (circles in the non-shaded area). Values inset give the percent change for sites in the grey domain only. Note the colourbar is uneven. 

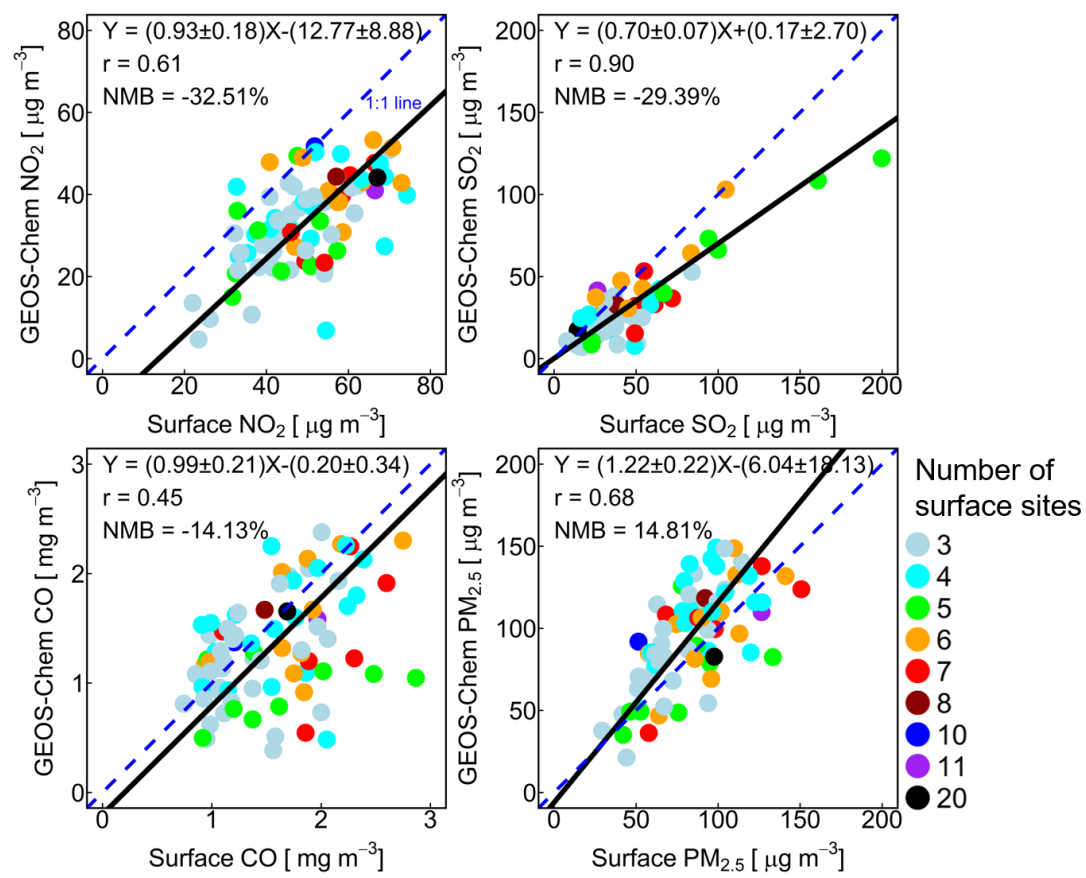

Figure 4. Evaluation of GEOS-Chem simulation of air pollutant concentrations in AW2016. Observations are averaged onto the GEOS-Chem grid. Points are simulated and observed $\mathrm{NO}_{2}$ (top left), $\mathrm{SO}_{2}$ (top right), $\mathrm{CO}$ (bottom left) and $\mathrm{PM}_{2.5}$ (bottom right) in the entire domain in Figure 3 for grid squares with at least three coincident surface sites. Points are coloured by the number of surface sites. The model uses scaled MEIC emissions (see text for details). RMA regression statistics, Pearson's correlation coefficients (r), and model normalized mean biases (NMB) are given. Lines are the RMA regression (black) and 1:1 line (blue dashed). 
https://doi.org/10.5194/acp-2021-428

Preprint. Discussion started: 2 August 2021

(c) Author(s) 2021. CC BY 4.0 License.
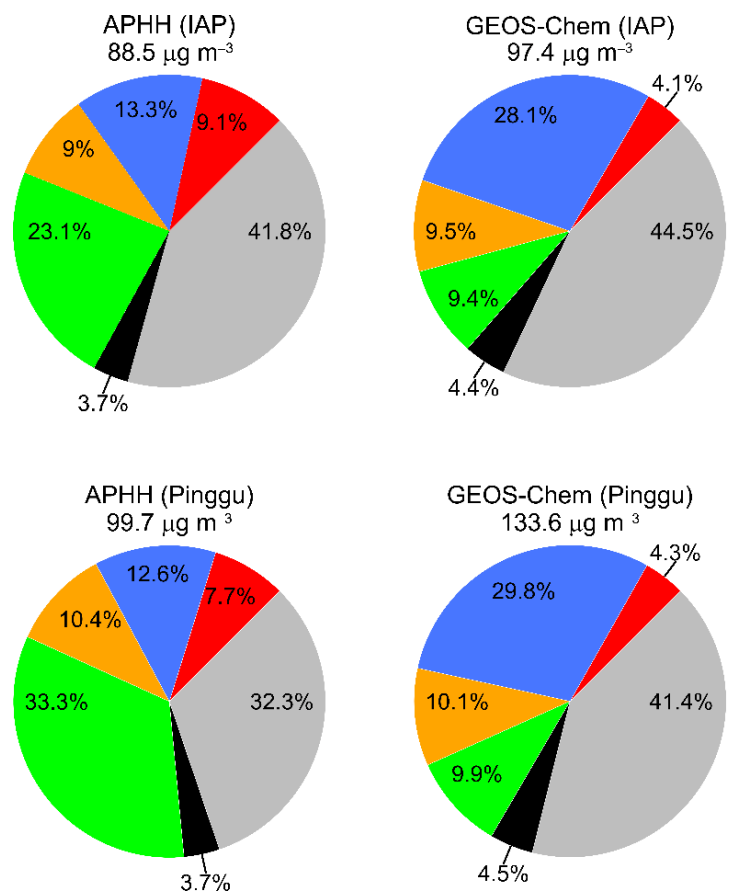

Sulfate
Nitrate
Ammonium
OC
BC
Other

Figure 5. Relative contribution of individual $\mathrm{PM}_{2.5}$ components during the APHH campaign. Panels are measured (left) and modelled (right) percent contribution for the urban IAP (top) and rural Pinggu (bottom) sites. Components are sulfate, nitrate, ammonium, OC, BC and Other. Other is the sum of trace metals, mineral dust and other ions, the non-carbon portion of OC, and aerosol water at 33-35\% relative humidity (RH) for the measurements and 35\% RH for the model. Values above the pies are mean total $\mathrm{PM}_{2.5}$. 
Figure 6. Total anthropogenic emissions in BTH in AW2016 and AW2017. Emissions are for grids covering the grey shaded area in Figure 3. Emissions are from the MEIC with scaling factors to address discrepancies between the model and observations for AW2016 and to reproduce the change in air pollutant concentrations in the AW2017 emission control period (see text for details). Vertical axes are emissions for $\mathrm{NO}, \mathrm{BC}, \mathrm{OC}$, and $\mathrm{SO}_{2}$ on the left axis and for $\mathrm{CO}$ on the right axis.
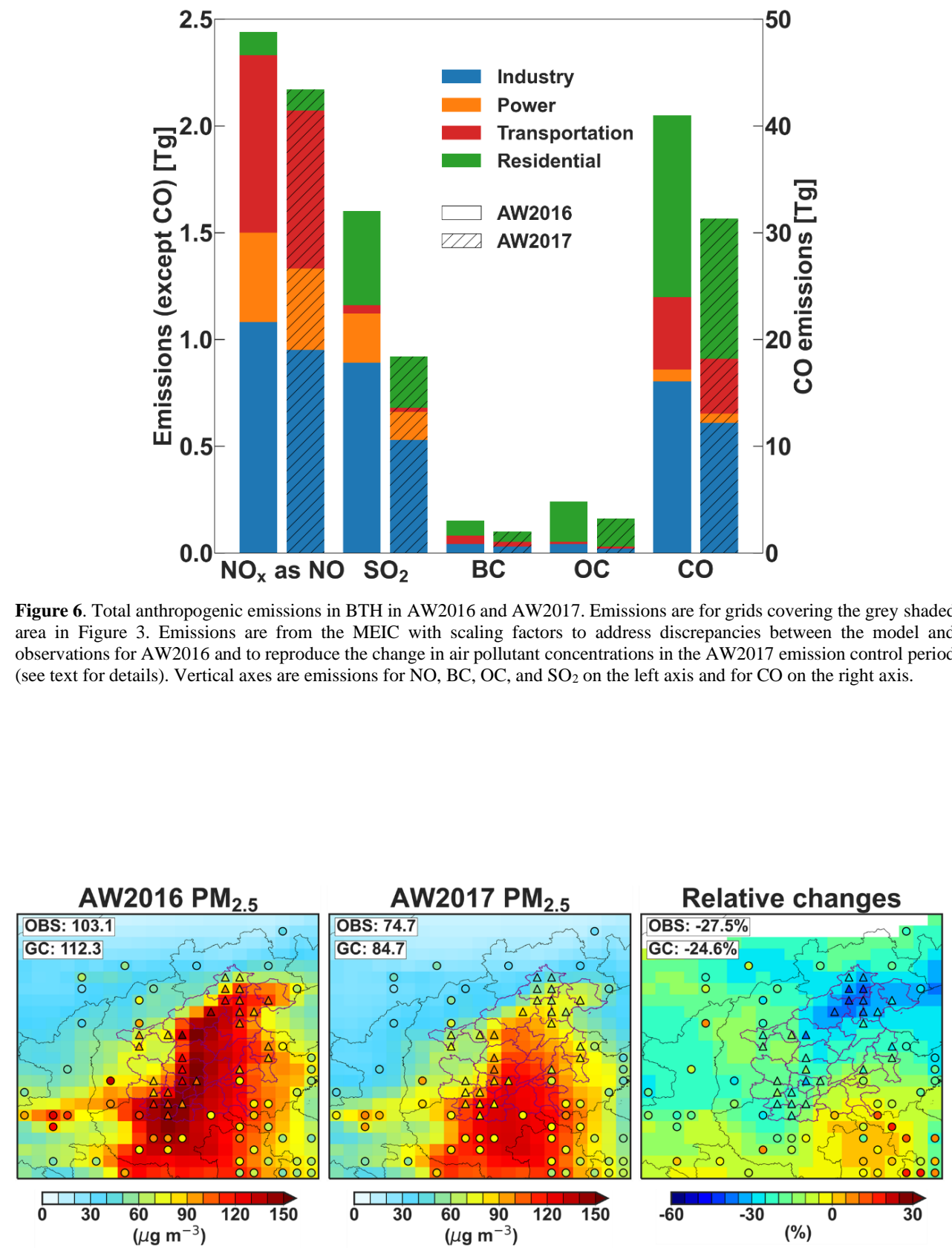

Figure 7. Spatial distribution of absolute and relative changes in observed and modelled $\mathrm{PM}_{2.5}$ before and during the strict emission control period. The observed (shapes) and modelled (background) PM2.5 are shown for AW2016 (left) and AW2017 (centre). The right panel is the relative change in observed and modelled PM $_{2.5}$. Observations are distinguished as within (triangles) and outside (circles) the emission control region (grey area in Figure 3). Inset values are the observed (OBS) and modelled (GC) means for sites and coincident grids in the emission control domain. Note the uneven colour scale in the right panel. 
https://doi.org/10.5194/acp-2021-428

Preprint. Discussion started: 2 August 2021

(c) Author(s) 2021. CC BY 4.0 License.

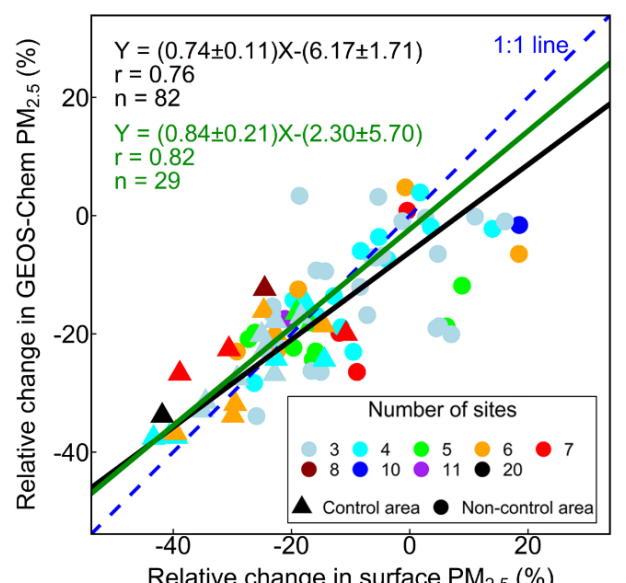

735 Figure 8. Comparison of observed and modelled relative changes in $\mathrm{PM}_{2.5}$. Triangles indicate data in BTH (grey area in Figure

736 3) and circles indicate data outside BTH. These are coloured by the number of sites in each GEOS-Chem grid. The RMA

737 regression statistics and lines, Pearson's correlation coefficients (r), and NMB are given for all points (black text) and for those 738 in BTH (green text). 